\title{
Green Aerospace Fuels From Nonpetroleum Sources
}

Aloysius F. Hepp

Glenn Research Center, Cleveland, Ohio

Michael J. Kulis and Ana B. De La Ree

United Negro College Fund Special Programs Corporation, Cleveland, Ohio

Robert Zubrin and Mark Berggren

Pioneer Astronautics, Lakewood, Colorado

Joseph D. Hensel

Polyflow LLC, Akron, Ohio

Michael C. Kimble

Reactive Innovations LLC, Westford, Massachusetts 


\section{NASA STI Program . . . in Profile}

Since its founding, NASA has been dedicated to the advancement of aeronautics and space science. The NASA Scientific and Technical Information (STI) program plays a key part in helping NASA maintain this important role.

The NASA STI Program operates under the auspices of the Agency Chief Information Officer. It collects, organizes, provides for archiving, and disseminates NASA's STI. The NASA STI program provides access to the NASA Aeronautics and Space Database and its public interface, the NASA Technical Reports Server, thus providing one of the largest collections of aeronautical and space science STI in the world. Results are published in both non-NASA channels and by NASA in the NASA STI Report Series, which includes the following report types:

- TECHNICAL PUBLICATION. Reports of completed research or a major significant phase of research that present the results of NASA programs and include extensive data or theoretical analysis. Includes compilations of significant scientific and technical data and information deemed to be of continuing reference value. NASA counterpart of peer-reviewed formal professional papers but has less stringent limitations on manuscript length and extent of graphic presentations.

- TECHNICAL MEMORANDUM. Scientific and technical findings that are preliminary or of specialized interest, e.g., quick release reports, working papers, and bibliographies that contain minimal annotation. Does not contain extensive analysis.

- CONTRACTOR REPORT. Scientific and technical findings by NASA-sponsored contractors and grantees.
- CONFERENCE PUBLICATION. Collected papers from scientific and technical conferences, symposia, seminars, or other meetings sponsored or cosponsored by NASA.

- SPECIAL PUBLICATION. Scientific, technical, or historical information from NASA programs, projects, and missions, often concerned with subjects having substantial public interest.

- TECHNICAL TRANSLATION. Englishlanguage translations of foreign scientific and technical material pertinent to NASA's mission.

Specialized services also include creating custom thesauri, building customized databases, organizing and publishing research results.

For more information about the NASA STI program, see the following:

- Access the NASA STI program home page at http://www.sti.nasa.gov

- E-mail your question via the Internet to help@ sti.nasa.gov

- Fax your question to the NASA STI Help Desk at $443-757-5803$

- Telephone the NASA STI Help Desk at 443-757-5802

- Write to: NASA Center for AeroSpace Information (CASI) 7115 Standard Drive Hanover, MD 21076-1320 
NASA/TM-2011-217027

AIAA-2011-702

\section{Green Aerospace Fuels From Nonpetroleum Sources}

Aloysius F. Hepp

Glenn Research Center, Cleveland, Ohio

Michael J. Kulis and Ana B. De La Ree

United Negro College Fund Special Programs Corporation, Cleveland, Ohio

Robert Zubrin and Mark Berggren

Pioneer Astronautics, Lakewood, Colorado

Joseph D. Hensel

Polyflow LLC, Akron, Ohio

Michael C. Kimble

Reactive Innovations LLC, Westford, Massachusetts

Prepared for the

49th Aerospace Sciences Meeting

sponsored by the American Institute of Aeronautics and Astronautics

Orland, Florida, January 4-7, 2011

National Aeronautics and

Space Administration

Glenn Research Center

Cleveland, Ohio 44135 


\section{Acknowledgments}

We acknowledge financial support from NASA's Fundamental Aeronautics (Sub-sonic Fixed Wing) and ETDD (ISRU) programs for in-house work. The NASA Education Office supported Drs. Mike Kulis and Ana De La Ree through the UNCFSP-UNEEC Energy and Environmental Studies Cluster. The NASA Small Business Innovative Research program supported work at Pioneer Aeronautics (Phase I, NNX10CD27P) and Reactive Innovations (Phase II, NNX10CA44C). We acknowledge the efforts of the following researchers: Profs. Joseph Gorse (Baldwin-Wallace College), D.R. Buffinger (Wilberforce Univ.), Michael Hoops (Wheeling Jesuit University), and Conrad Jones (Southern University); our colleagues: Jennifer Klettlinger, Lauren Best, and Daniel Scheiman; and student researchers: Sidney Jones, Peter Psarras, Jonathan Cowen, Robyn Bradford, Detron Brown and Amber Abbott. We acknowledge a gift of high surface area alumina support material from Sasol North America Inc. Drs. Kurt Sacksteder and Geoffrey Landis of NASA GRC are acknowledged for technical discussions and insights.

This report contains preliminary findings, subject to revision as analysis proceeds.

Trade names and trademarks are used in this report for identification only. Their usage does not constitute an official endorsement, either expressed or implied, by the National Aeronautics and Space Administration.

Level of Review: This material has been technically reviewed by technical management.

Available from

NASA Center for Aerospace Information 7115 Standard Drive Hanover, MD 21076-1320
National Technical Information Service 5301 Shawnee Road Alexandria, VA 22312 


\title{
Green Aerospace Fuels From Nonpetroleum Sources
}

\author{
Aloysius F. Hepp \\ National Aeronautics and Space Administration \\ Glenn Research Center \\ Cleveland, Ohio 44135 \\ Michael J. Kulis and Ana B. De La Ree \\ United Negro College Fund Special Programs Corporation \\ Cleveland, Ohio 44135 \\ Robert Zubrin and Mark Berggren \\ Pioneer Astronautics \\ Lakewood, Colorado 80215 \\ Joseph D. Hensel \\ Polyflow LLC \\ Akron, Ohio 44308 \\ Michael C. Kimble \\ Reactive Innovations LLC \\ Westford, Massachusetts 01886
}

\begin{abstract}
Efforts to produce green aerospace propellants from nonpetroleum sources are outlined. The paper begins with an overview of feedstock processing and relevant small molecule or $\mathrm{C} 1$ chemistry. Gas-toliquid technologies, notably Fischer-Tropsch (FT) processing of synthesis gas $\left(\mathrm{CO}\right.$ and $\left.\mathrm{H}_{2}\right)$, are being optimized to enhance the fraction of product stream relevant to aviation (and other transportation) fuels at the NASA Glenn Research Center (GRC). Efforts to produce optimized catalysts are described. Given the high cost of space launch, the recycling of human metabolic and plastic wastes to reduce the need to transport consumables to orbit to support the crew of a space station has long been recognized as a high priority. If the much larger costs of transporting consumables to the Moon or beyond are taken into account, the importance of developing waste recycling systems becomes still more imperative. One promising way to transform organic waste products into useful gases is steam reformation; this wellknown technology is currently being optimized by a Colorado company for exploration and planetary surface operations. Reduction of terrestrial waste streams while producing energy and/or valuable raw materials is an opportunity being realized by a new generation of visionary entrepreneurs. A technology that has successfully demonstrated production of fuels and related chemicals from waste plastics developed in Northeast Ohio is described. Technologies being developed by a Massachusetts company to remove sulfur impurities are highlighted. Common issues and concerns for nonpetroleum fuel production are emphasized. Energy utilization is a concern for production of fuels whether a terrestrial operation or on the lunar (or Martian) surface; the term green relates to not only mitigating excess carbon release but also to the efficiency of grid-energy usage. For space exploration, energy efficiency can be an essential concern. Other issues of great concern include minimizing impurities in the product stream(s), especially those that potential health risks and/or could degrade operations through catalyst poisoning or equipment damage. The potential impacts on future missions by such concerns are addressed in closing.
\end{abstract}




\section{Nomenclature}

$\begin{array}{ll}\text { BDE } & \text { bond dissociation energies } \\ \mathrm{BET} & \text { Brunauer, Emmett, and Teller, surface area analysis method } \\ \mathrm{C} 1 & \text { generic term for single carbon compounds } \\ \mathrm{CH}_{4} & \text { methane or natural gas } \\ \mathrm{C}_{2} \mathrm{H}_{4} & \text { ethylene (or ethene), a starting material for polyethylene } \\ \mathrm{CO} & \text { carbon monoxide } \\ \mathrm{CO}_{2} & \text { carbon dioxide } \\ \mathrm{CSTR} & \text { continuously-stirred tank reactor } \\ \text { ETDD } & \text { Exploration Technology Development and Demonstration program } \\ \text { FT(S) } & \text { Fischer-Tropsch (synthesis) } \\ \text { ISRU } & \text { In Situ Resource Utilization (program) } \\ \text { LOWR } & \text { Lunar organic waste reformer } \\ \text { MIM } & \text { 3-methylimidazolium } \\ \text { MMBTU } & \text { Millions of BTUs } \\ \text { RWGS } & \text { reverse water-gas shift reaction } \\ \text { SEM } & \text { scanning electron microscopy } \\ \text { TEM } & \text { transmission electron microscopy } \\ \text { TGA } & \text { thermogravimetric analysis, a thermal analysis method } \\ \text { TPR } & \text { temperature-programmed reduction, a chemi-sorption analysis method } \\ \text { WGS } & \text { water-gas shift reaction }\end{array}$

\section{Introduction}

Fossil fuels have enabled rapid technological advances in modern transportation for two centuries. The industrial revolution led to the railroads and steamships of the nineteenth century that were powered by plentiful coal. Transportation in the twentieth century was fostered by the ready availability and low prices of various petroleum products. Several realities emerged in the late twentieth century to force a rethinking of an over-reliance on nonrenewable fossil fuels: the environmental impact of their usage, complex geo-politics and security ramifications, and eventually the dwindling supplies of this essential but nonrenewable resource. While there are certainly alternatives to petroleum-based transportation such as fuel cell or other electric land and nuclear maritime propulsion, aviation and space transportation require high-energy-density fuels. In this survey paper, we describe efforts at NASA Glenn Research Center and several industrial partners research laboratories related to the production of green transportation fuels for aviation and space from nonpetroleum sources and related issues.

Gas-to-liquid technologies, notably Fischer-Tropsch (FT) processing of synthesis gas $\left(\mathrm{CO}\right.$ and $\left.\mathrm{H}_{2}\right)$, are critical industrial processes that produce a complex product stream useful for transportation fuels and chemicals. The first section describes efforts at NASA Glenn to produce Fischer-Tropsch synthesis (FTS) catalysts that target the saturated hydrocarbon fraction of the product stream $\left(\mathrm{C}_{8}\right.$ to $\mathrm{C}_{18}$ hydrocarbons $)$, as this material is most similar to JP-8, an aviation fuel useful for commercial and military jets. Other activities at NASA include molecular modeling to help guide catalyst fabrication to enhance aviation fuel production and design new catalysts to aid in the breakdown of waste materials to eventually produce fuels; efforts to produce optimized catalysts are described. 
Given the high cost of space launch, the recycling of human metabolic and plastic wastes to reduce the need to transport consumables for crew support on the space station has long been recognized as a high priority. If the much larger costs of transporting consumables to the Moon or beyond are taken into account, the importance of developing waste recycling systems becomes still more imperative. One promising way to transform organic waste products into useful gases is steam reformation; this wellknown technology is currently being optimized by a Colorado company for exploration and planetary surface operations.

Reduction of waste streams while producing energy and/or valuable raw materials is an opportunity being realized by a new generation of visionary entrepreneurs. A technology that has successfully demonstrated production of fuels and related chemicals from waste plastics developed in Northeast Ohio is described. Other issues such as impurity removal, environmental durability and technology readiness are discussed to give a more complete technology assessment. Technologies being developed by a Massachusetts company to remove sulfur impurities are highlighted. Production of fuels on the lunar (or Martian) surface will likely be a very power intensive process. The power system must be capable of providing electrical and thermal power for fuel production; we discuss significant issues related to stable power generation. Common issues and concerns for terrestrial and nonterrestrial nonpetroleum fuel production are emphasized; we begin with an overview of feedstock processing and $\mathrm{C} 1$ chemistry.

\section{Overview of C1 Chemistry and Feedstock Processing}

A brief consideration of $\mathrm{C} 1$ and related chemistry provides a context for a discussion of the relevant processing options, systems issues and related technologies (Ref. 1). C1 chemistry refers to reactions that convert single-carbon sources (i.e., methane, carbon dioxide, carbon monoxide, and here, carbon soot) into green and/or ultra-clean aerospace fuels. The primary raw material for production of fuels is synthesis (or syn-) gas (hydrogen and carbon monoxide) produced by gasifying coal, reforming or partial oxidation of natural gas (methane), and reforming carbon dioxide. The enthalpy $(\Delta \mathrm{H})$ or total energy change of the reaction is an indication of whether the transformation releases energy (exothermic, negative $\Delta \mathrm{H}$ ) or requires energy input (endothermic, positive $\Delta \mathrm{H}$ ). Depending upon the application or desired products, combining endothermic and exothermic reactions minimizes the energy that must be added to the overall system.

In the gaslight era, for example, the destructive distillation of coal was used to produce synthesis (or syn-) gas (called "town gas" at the time) via reaction (1):

$$
\mathrm{C}+\mathrm{H}_{2} \mathrm{O}=>\mathrm{CO}+\mathrm{H}_{2} \quad \Delta \mathrm{H}=+31 \mathrm{kcal} / \mathrm{mol}
$$

If more steam is available, the $\mathrm{CO}$ will be converted to $\mathrm{CO}_{2}$ via the water gas shift (WGS) reaction (2):

$$
\mathrm{CO}+\mathrm{H}_{2} \mathrm{O}=>\mathrm{CO}_{2}+\mathrm{H}_{2} \quad \Delta \mathrm{H}=-9 \mathrm{kcal} / \mathrm{mol}
$$

Taken together, the net result of reactions (1) and (2) is reaction (3):

$$
\mathrm{C}+2 \mathrm{H}_{2} \mathrm{O}=>\mathrm{CO}_{2}+2 \mathrm{H}_{2} \quad \Delta \mathrm{H}=+22 \mathrm{kcal} / \mathrm{mol}
$$

Synthesis gas can also be produced by two endothermic reactions, carbon dioxide reforming of methane, reaction (4), and the steam reforming of methane (5) producing a greater than 1:1 hydrogen to carbon monoxide ratio:

$$
\begin{gathered}
2 \mathrm{CH}_{4}+\mathrm{CO}_{2}=>2 \mathrm{CO}+4 \mathrm{H}_{2} \quad \Delta \mathrm{H}=+59 \mathrm{kcal} / \mathrm{mol} \\
\mathrm{CH}_{4}+\mathrm{H}_{2} \mathrm{O}=>\mathrm{CO}+3 \mathrm{H}_{2} \quad \Delta \mathrm{H}=+49 \mathrm{kcal} / \mathrm{mole}
\end{gathered}
$$


In general, steam reformation can be used to produce mixtures of $\mathrm{CO}_{2}, \mathrm{H}_{2}$, and $\mathrm{CO}$ from any organic material. For example we can also steam reform methane via reaction (6) to produce a 4:1 hydrogen to carbon dioxide ratio by essentially combining steam reforming (reaction (5)) with the WGS (reaction (2)):

$$
\mathrm{CH}_{4}+2 \mathrm{H}_{2} \mathrm{O} \Rightarrow \mathrm{CO}_{2}+4 \mathrm{H}_{2} \quad \Delta \mathrm{H}=+40 \mathrm{kcal} / \mathrm{mol}
$$

Steam reformation of ethylene, the building block of polyethylene plastic occurs via (7):

$$
\mathrm{C}_{2} \mathrm{H}_{4}+4 \mathrm{H}_{2} \mathrm{O}=>2 \mathrm{CO}_{2}+6 \mathrm{H}_{2} \quad \Delta \mathrm{H}=+104 \mathrm{kcal} / \mathrm{mol}
$$

Steam reformation of all kinds of biomass can also readily be done, with a typical reaction shown in reaction (8):

$$
\mathrm{C}_{6} \mathrm{H}_{12} \mathrm{O}_{6}+6 \mathrm{H}_{2} \mathrm{O}=>6 \mathrm{CO}_{2}+12 \mathrm{H}_{2} \quad \Delta \mathrm{H}=+145 \mathrm{kcal} / \mathrm{mol}
$$

Comparing reactions (3) through (8) we note that while the total $\Delta \mathrm{H}$ of each reaction varies significantly, the $\Delta \mathrm{H}$ per total moles of gas produced (summing $\mathrm{CO}$ or $\mathrm{CO}_{2}$ and $\mathrm{H}_{2}$ ) only varies from 8 to $13 \mathrm{kcal} / \mathrm{mole}$. Finally, several exothermic reactions are often included to improve the overall system enthalpy or modify the product mix. The partial oxidation of methane (reaction (9)) is another syn-gas production process. The total oxidation (combustion) of methane (reaction (10)) is quite exothermic because it produces $\mathrm{CO}_{2}$. The Sabatier process (reaction (11)) is the reverse of reaction (6).

$$
\begin{array}{cc}
\mathrm{CH}_{4}+1 / 2 \mathrm{O}_{2}=>\mathrm{CO}+2 \mathrm{H}_{2} & \Delta \mathrm{H}=-9 \mathrm{kcal} / \mathrm{mol} \\
\mathrm{CH}_{4}+2 \mathrm{O}_{2}=>\mathrm{CO}_{2}+2 \mathrm{H}_{2} \mathrm{O} & \Delta \mathrm{H}=-213 \mathrm{kcal} / \mathrm{mol} \\
\mathrm{CO}_{2}+4 \mathrm{H}_{2}=>\mathrm{CH}_{4}+2 \mathrm{H}_{2} \mathrm{O} & \Delta \mathrm{H}=-40 \mathrm{kcal} / \mathrm{mol}
\end{array}
$$

The Fischer-Tropsch (FT) reaction (reaction (12)) is the reverse of reaction (5), steam reforming of methane for $n=1$. Fischer-Tropsch synthesis (FTS) is an industrial gas-to-liquid (GTL) processing technology for producing higher hydrocarbons from syn-gas (Refs. 2 to 4). Because FTS is exothermic, it is a prime candidate for combining with endothermic reactions, such as the reforming reactions ((3) through (8)) discussed previously to minimize energy input to the complete unit operation or system. A summary of FTS catalyst development and simple polymer waste processing with related catalysts at NASA GRC is discussed in the following section.

$$
(2 \mathrm{n}+1) \mathrm{H}_{2}+\mathrm{n} \mathrm{CO}=>\mathrm{C}_{\mathrm{n}} \mathrm{H}_{(2 \mathrm{n}+2)}+\mathrm{n} \mathrm{H}_{2} \mathrm{O} \quad \Delta \mathrm{H}=-49 \mathrm{kcal} / \mathrm{mol}(\mathrm{n}=1)
$$

Finally, several endothermic reactions are included that describe production of hydrogen from methane (13) and water (14). It is important to note that the enthalpies used are standard numbers that are subject to some variation due to phase, temperature, and pressure. Both reactions (13) and (14) require high temperatures and catalysts.

$$
\begin{gathered}
\mathrm{CH}_{4}=>\mathrm{C}+2 \mathrm{H}_{2} \quad \Delta \mathrm{H}=+18 \mathrm{kcal} / \mathrm{mol} \\
\mathrm{H}_{2} \mathrm{O}=>1 / 2 \mathrm{O}_{2}+2 \mathrm{H}_{2} \quad \Delta \mathrm{H}=+68 \mathrm{kcal} / \mathrm{mol}
\end{gathered}
$$




\section{Fundamental Studies of Catalyst and Polymer Processing for Green Fuel Production}

Efforts at NASA Glenn Research Center for producing green fuels using nonpetroleum feedstocks support both the Sub-sonic Fixed Wing program of Fundamental Aeronautics and the In Situ Resource Utilization (ISRU) program of the Exploration Technology Development and Demonstration (ETDD) program. The nonpetroleum feedstocks include: bio-mass, salt-tolerant plants and algae, syn-gas, waste plastic, and gas streams derived from one or more second-generation waste conversion processes (discussed below). The primary activities discussed herein include: FTS catalyst processing and characterization, catalyst modeling, polymer processing, and novel process development and characterization.

\section{FTS Catalyst Processing and Characterization}

As the oil supply dwindles, there is a greater need for (cleaner) alternative fuels and/or feedstocks (Refs. 1 to 3). Also, there is likely to be a shift from crude oil to natural gas as a feedstock for the chemical industry. In order to meet the new demand, FT processes will be critical for gas-to-liquid conversions. Fisher-Tropsch processes can produce a cleaner diesel oil fraction with a high cetane number (typically above 70) without any sulfur and aromatic compounds (Refs. 4 and 5); it uses a feedstock of carbon monoxide and hydrogen (syn-gas), in which the gas is converted into various liquid hydrocarbons. Typical FTS is catalyzed by cobalt supported on alumina, silica, or titania or unsupported alloyed iron powders. Cobalt is typically used more often than iron; cobalt is a longer-active catalyst, has less watergas shift activity, and lower production of modified products such as oxygen-containing molecules (alcohols, aldehydes, ketones, etc.) (Ref. 6).

One object of the effort at NASA GRC is to develop multiple FTS catalysts to use in the Alternative Fuels Research Laboratory, a hydrocarbon processing facility with three continuously-stirred tank reactors (CSTRs), see Figure 1. The catalysts were prepared and fully characterized by various analytical techniques: chemical analysis, scanning electron microscopy, chemi- (temperature programmed reduction or TPR) and physi-sorption (Brunauer, Emmett, and Teller or BET) analysis, and transmission electron microscopy (TEM). The goal is to enhance the fraction of the FTS reaction that can be used for aviation fuel (saturated $\mathrm{C}_{8}$ to $\mathrm{C}_{18}$ hydrocarbons) or additives. As we develop a better understanding of the correlation of the preparation and activity of catalysts, promoters were to be added to the supported FTS catalysts.

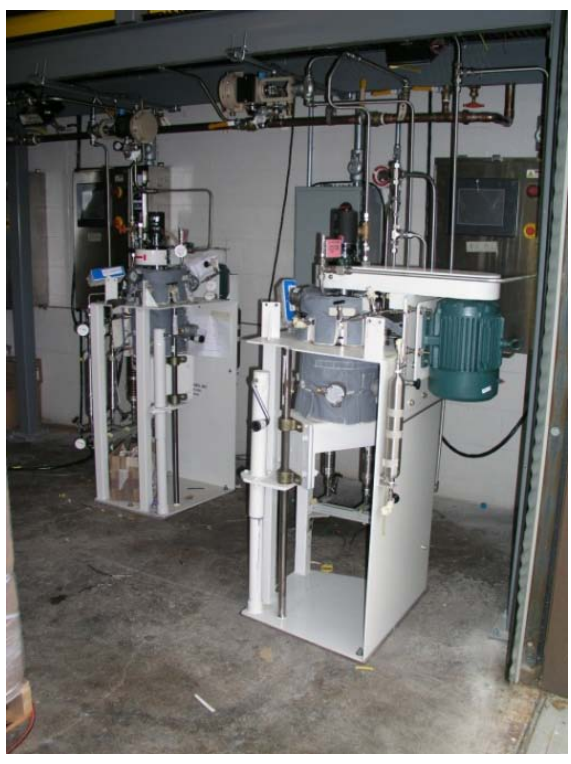

Figure 1.-NASA GRC Alternative Fuels Laboratory (CSTR facilities). 
Addition of transition metals as promoters is one well-studied method to enhance the catalytic properties of FTS catalysts. The more common promoters used in FTS are rhenium, platinum, and ruthenium. Eri and coworkers were the first to add rhenium to cobalt/alumina catalysts (Ref. 7). Diaz and coworkers have shown that rhenium can enhance the reducibility of cobalt oxides as well as increasing catalytic activity (Ref. 8). Promoters are valuable in improving Fischer-Tropsch catalysts as they can increase cobalt oxide dispersion, promote reduction of cobalt oxide to the active metal phase, stabilize a high metal surface area, and improve mechanical properties (Ref. 9). In order to look for lower cost alternatives to the platinum-group metals we are looking at alternatives such as silver and manganese; platinum is also being studied as a comparison to the literature.

The preparations of the different catalysts were initially based on a description in a U.S patent by Espinoza et al. (Ref. 10). We initially modified examples from the patent to prepare four different catalysts, known as Procedures 1-4, with varying degrees of cobalt dispersion. After initial characterization of these four catalyst-processing methods, we further adjusted two of the procedures to prepare catalysts with silver, platinum, and manganese promoters. We also used a more conventional or incipient wetness process. Figures 2 and 3 show the facilities in use at NASA GRC for preparation of heterogeneous catalysts including rotary evaporation and a calcining furnace designed and built in house, respectively.

To this point, over 25 samples of heterogeneous Co on alumina catalyst materials have been prepared with different loadings of $\mathrm{Co}$ as determined by chemical analysis, various levels of dispersion, as determined by TEM, and different promoters at different loadings, again by chemical analysis. Physi- and chemi-soprtion data are included, when available. A representative sampling of FTS catalysts prepared at NASA GRC is given in Table 1. While we are just beginning to run these catalysts in the recentlycommissioned CSTR facility, preliminary data shows that Ru and Pt are still better promoters than Ag and $\mathrm{Mn}$, as determined by lower temperature in TPR. We are also able to modify the surface area (BET) by modifying the fabrication process. Scanning electron microscopy (Figs. 4 and 5) and TEM (Figs. 6 and 7) data of representative samples are shown below.

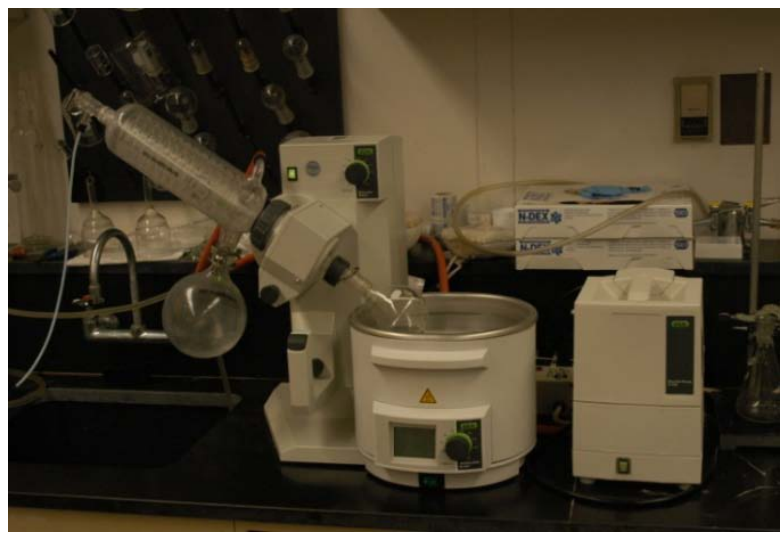

Figure 2.-Rotary evaporation unit in catalyst preparation facility at NASA GRC.

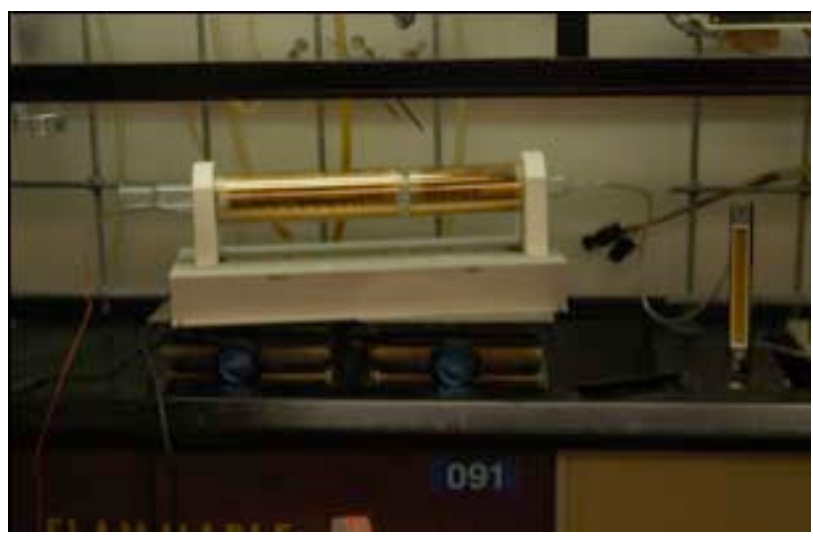

Figure 3.-Multi-purpose furnace, designed and built at NASA GRC for calcining catalysts. 
TABLE 1.-REPRESENTATIVE SAMPLES OF CO ON ALUMINA FTS CATALYSTS PREPARED AT NASA GRC

\begin{tabular}{|l|c|c|c|c|c|c|c|}
\hline \multicolumn{1}{|c|}{ Sample } & $\begin{array}{c}\text { Amount, } \\
\mathrm{g}\end{array}$ & Method & Promoter & $\%$ Co & $\%$ Prom. & $\begin{array}{c}\text { BET, } \\
\mathrm{m}^{2} / \mathrm{g}\end{array}$ & $\begin{array}{c}\text { TPR, } \\
{ }^{\circ} \mathrm{C}\end{array}$ \\
\hline $060209-40-C A-W$ & 17.8 & Nondisperse & None & 31.8 & N/A & 105.2 & -------- \\
\hline $072309-40-C A-W$ & 7.48 & Hi-disperse & None & 9.3 & N/A & 142.4 & -------- \\
\hline $060909-25-C A-W$ & 11.94 & Low-disperse & None & 20.9 & N/A & 101.9 & -------- \\
\hline $071409-60-C A-W$ & 20.34 & Med-disperse & None & 21.6 & N/A & 126.4 & -------- \\
\hline $072009-40$ Co-1-Pt-CA & 15.83 & Med-disperse & Platinum & 21.5 & 0.85 & 123.7 & -------- \\
\hline $072009-40 C o-1-A g-C A$ & 15.88 & Med-disperse & Silver & 21.0 & 0.81 & 118.2 & -------- \\
\hline 100722MDH2 & 9.54 & Med-disperse & Manganese & 21.2 & 0.62 & -------- & -------- \\
\hline 100715RGA & 30 & Incip. Wet. & Manganese & 25.7 & 0.59 & 103.2 & 366.8 \\
\hline 100723RGA & 30 & Incip. Wet. & Ruthenium & 23.0 & 2.20 & 123.9 & 184.6 \\
\hline 100519JSK & 30 & Incip. Wet. & Platinum & 25.6 & 0.15 & 144.9 & -------- \\
\hline
\end{tabular}

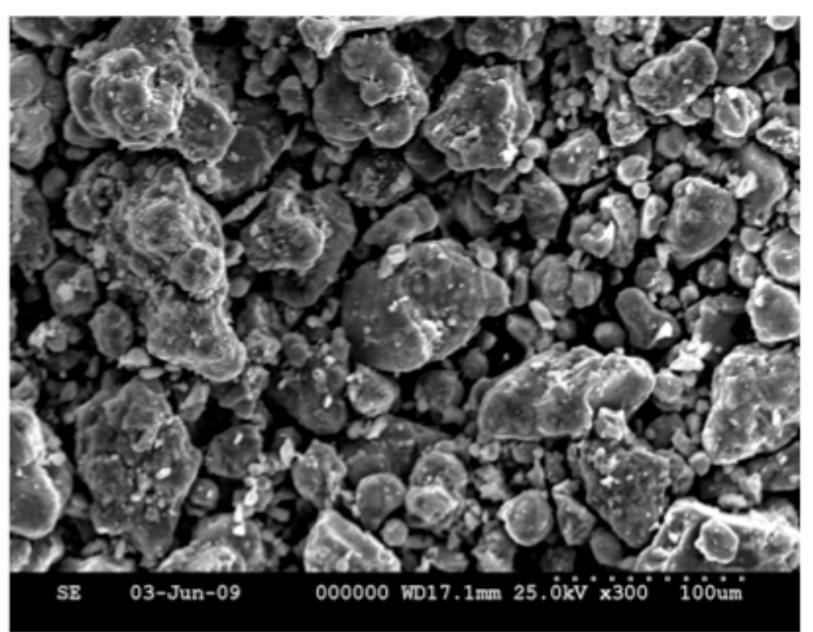

Figure 4.- SEM of unpromoted Co on alumina, nondispersed sample.

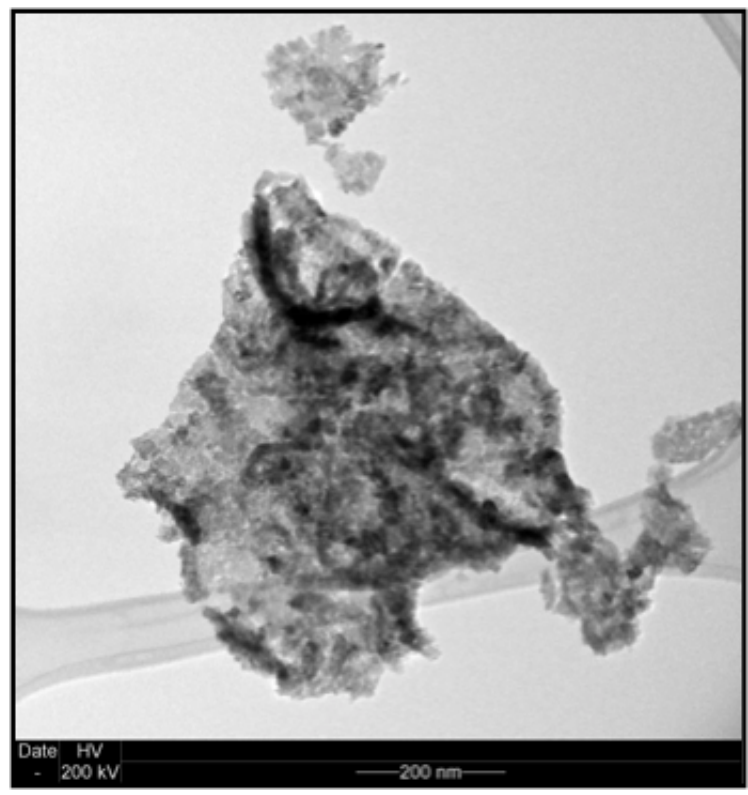

Figure 6.-TEM of unpromoted Co on alumina, poorly dispersed sample, note Co concentration variation on alumina support.

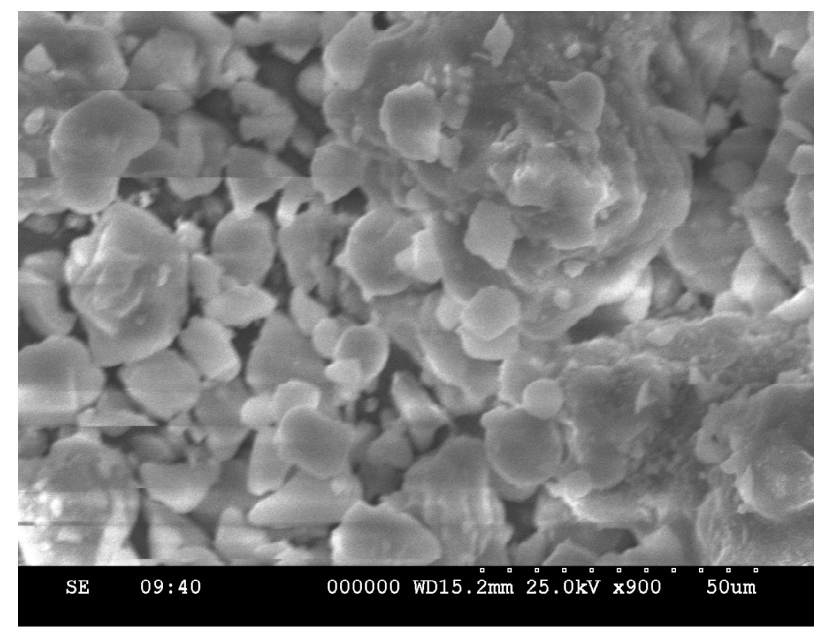

Figure 5.-SEM of Ag-promoted Co on alumina, medium dispersion sample.

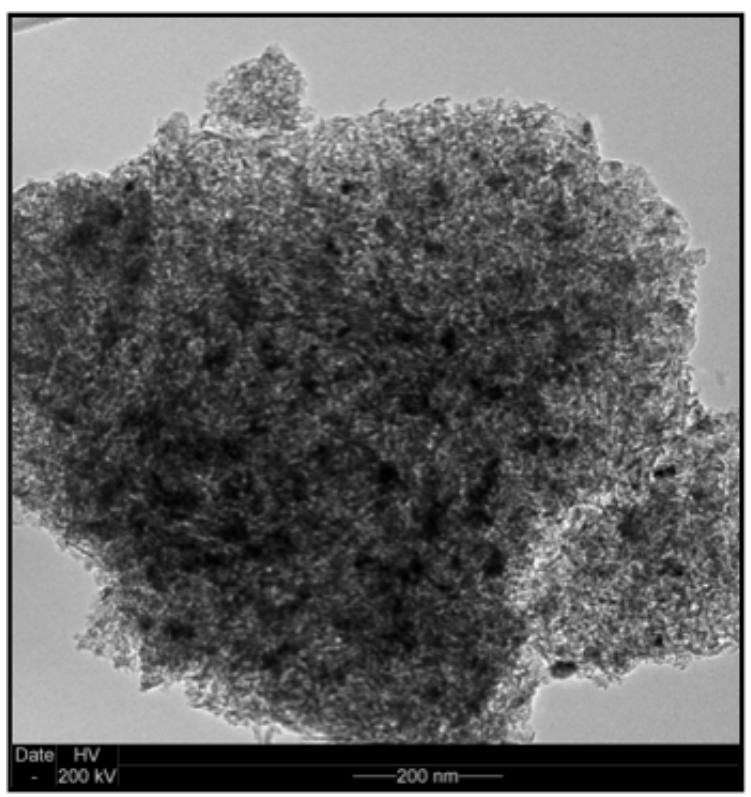

Figure 7.-TEM of unpromoted Co on alumina, well-dispersed sample, note homogeneity of Co on alumina support. 


\section{Molecular Modeling of Metal Carbonyl Species and Relevance to FTS}

Fischer-Tropsch synthesis involves reactions on a metallic surface, which acts as a catalyst (Ref. 3). The FTS mechanism is widely believed to consist of three types of surface reactions: initiation, propagation, and termination. The initiation reactions involve the adsorption of carbon monoxide (CO) and diatomic hydrogen $\left(\mathrm{H}_{2}\right)$ and their subsequent dissociation to generate the hydrocarbon precursors. The propagation reactions consist of hydrogenation and carbon-carbon coupling reactions. Lastly, the termination reactions involve the formation of weakly bound hydrocarbons that desorb from the metal surface. The balance between all of the reactions in the process determines the reaction products.

The most-common catalysts used in Fischer-Tropsch synthesis are the transition metals nickel, ruthenium, iron, and cobalt (Ref. 2). Nickel is a very active hydrogenation catalyst resulting in the production of a large quantity of methane. Nickel is therefore an unsuitable catalyst for FTS. Ruthenium is the most active catalyst at the lowest temperature. However, Ruthenium is far too expensive due to its limited supply and is exclusively of scientific interest. Iron is an inexpensive and versatile catalyst. However, it suffers from inhibition by water, which is a byproduct of Fischer-Tropsch synthesis. Cobalt is more hydrogenating than iron as a catalyst and subsequently produces more methane and less singlyunsaturated hydrocarbons or olefins. It is also more expensive than iron. However, cobalt has gained increased interest mostly due to the fact that it doesn't suffer inhibition by water.

In preliminary molecular modeling efforts, structures of metal carbonyls of nickel, iron, and cobalt were used as simple analogies to metal surfaces with adsorbed CO. The bond dissociation energy (BDE) of the metal-carbon bond (M-C) and the BDE of the carbon-oxygen bond $(\mathrm{C}-\mathrm{O})$ were determined using first principal calculations ( $a b$ initio). The BDE of M-C may be useful as an indication of how well CO adsorbs onto a particular metal surfaces. Whereas, the BDE of C-O may be useful to determine the optimal catalyst since dissociation of C-O is a critical step in the FT process.

Gaussian 03 (Ref. 11) with GaussView 5 (Ref. 11) as the graphical user interface were used for the modeling of metal carbonyls. GaussView 5 is used to construct the structure of model with its molecule building facility. Gaussian 03 performs the calculations based on the structure and the instructions provided. The instructions include the type of calculations to be performed along with the mathematical method to be used to build the model and the basis set that define the space occupied by the molecular orbitals of the model.

Two steps were involved in the determination of the BDE's. In the first step, a geometry optimization was performed on each model. The geometry optimizations are used to locate minima on the potential energy surface of the model in order to predict equilibrium geometries; these are shown in Figure 8. For Co carbonyl and Fe carbonyl, carbonyl ligands are distinguished based on molecular symmetry. In the second step, the BDE of a particular bond within the optimized structure is determined by incrementally increasing the bond length and calculating the energy at each step. The energy value converges to the BDE value as the bond length increases. Shown in Figure 9 are plots of energy versus distance from equilibrium bond length of $\mathrm{M}-\mathrm{C}$ for three different metal carbonyls.
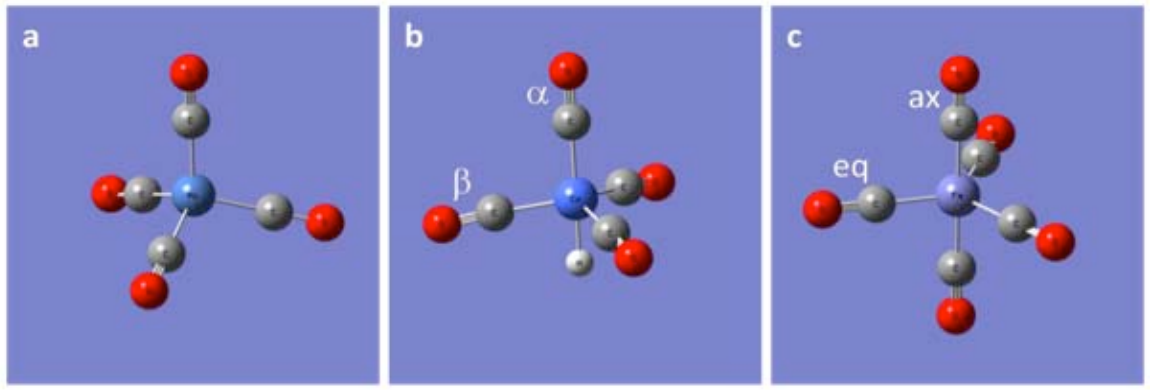

Figure 8.-Optimized geometries of three different metal carbonyl models: $\left(\mathrm{a}-\mathrm{Ni}(\mathrm{CO})_{4}\right),\left(\mathrm{b}-\mathrm{CoH}(\mathrm{CO})_{4}\right)$, and $\left(\mathrm{c}-\left(\mathrm{Fe}(\mathrm{CO})_{5}\right)\right.$. 


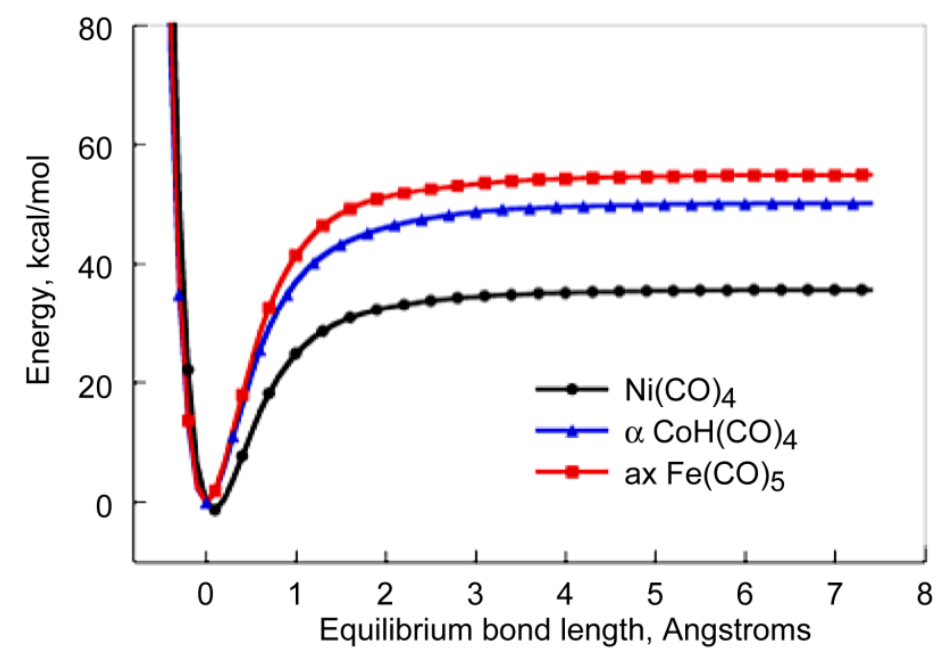

Figure 9.- $\mathrm{M}-\mathrm{C}$ bond lengths, energy versus distance from equilibrium.

TABLE 2.-BOND DISSOCIATION ENERGIES OF CARBON MONOXIDE AND METAL CARBONYLS AND DIFFERENCES FROM CO

\begin{tabular}{|l|c|c|c|}
\hline Model structure & $\begin{array}{c}\text { Energy }(\mathrm{kcal} / \mathrm{mol}) \\
\mathrm{M}-\mathrm{C}\end{array}$ & $\begin{array}{c}\text { Energy }(\mathrm{kcal} / \mathrm{mol}) \\
\mathrm{C}-\mathrm{O}\end{array}$ & $\begin{array}{c}\Delta \text { Energy }(\mathrm{kcal} / \mathrm{mol}) \\
\text { C-O }\end{array}$ \\
\hline $\mathrm{CO}$ & $\mathrm{NA}$ & 325.20 & ------- \\
\hline $\mathrm{Ni}(\mathrm{CO})_{4}$ & 35.61 & 297.00 & -28.20 \\
\hline$\beta-\mathrm{CoH}(\mathrm{CO})_{4}$ & 47.60 & 271.37 & -53.83 \\
\hline$\alpha-\mathrm{CoH}(\mathrm{CO})_{4}$ & 50.04 & 269.15 & -56.05 \\
\hline $\mathrm{ax}-\mathrm{Fe}(\mathrm{CO})_{5}$ & 54.88 & 258.19 & -62.07 \\
\hline eq-Fe$(\mathrm{CO})_{5}$ & 76.91 & 263.14 & -67.01 \\
\hline
\end{tabular}

The optimized geometries as well as energies at each bond length for selected bonds were determined using density functional theory as the mathematical method. Density functional theory uses "functionals" to describe the electron density in a molecule instead of the traditional method of using complicated many-electron wavefunctions. Specifically, the functional used in this work was the common B3PW91 (Ref. 12). The basis set used to describe the space occupied by the molecular orbital was the LanL2Dz (Ref. 13), that has an effective core for atoms larger than Neon, necessary to model the relatively large atomic centers investigated in this effort.

Table 2 contains the BDE's of M-C and C-O for the metal carbonyl compounds considered in this work. DFT methods have a tendency to overestimate metal-lig and bond dissociations (Ref. 14). This is the case in this work as well. For example, the experimental value for the BDE of the axial Fe-C is $42 \mathrm{kcal} / \mathrm{mol}$ as compared to the calculated value of $54.88 \mathrm{kcal} / \mathrm{mol}$ (Ref. 15). However, the trend is the same as the experimental values with iron providing the strongest metal carbonyl bond and nickel providing the weakest (Refs. 15 to 17). It is inferred from this result that the trend established by the calculated BDE's of C-O can be considered with confidence as well.

In order to further the analogy of metal carbonyls as catalytic surfaces, heterogeneous binuclear carbonyl models were constructed to represent the addition of a promoter on a surface. In particular, cobalt carbonyl compounds containing Group IB metals were used to represent cobalt surfaces promoted by copper, silver, or gold. Table 3 contains the BDE's of $\mathrm{M}-\mathrm{C}$ and $\mathrm{C}-\mathrm{O}$ for the bimetallic carbonyl structures considered in this work. 
TABLE 3.-BOND DISSOCIATION ENERGY OF BINUCLEAR COBALT CARBONYLS AND DIFFERENCES FROM COH(CO $)_{4}$

\begin{tabular}{|l|c|c|c|}
\hline Model structure & $\begin{array}{c}\text { Energy (kcal/mol) } \\
\text { Co-C }\end{array}$ & $\begin{array}{c}\text { Energy }(\mathrm{kcal} / \mathrm{mol}) \\
\text { C-O }\end{array}$ & $\begin{array}{c}\Delta \text { Energy }(\mathrm{kcal} / \mathrm{mol}) \\
\text { C-O }\end{array}$ \\
\hline$\alpha-\mathrm{CoH}(\mathrm{CO})_{4}$ & 50.04 & 269.15 & ------ \\
\hline $\mathrm{CoCu}(\mathrm{CO})_{4}$ & 55.74 & 259.42 & -9.73 \\
\hline $\mathrm{CoAg}(\mathrm{CO})_{4}$ & 55.18 & 257.24 & -11.91 \\
\hline $\mathrm{CoAu}(\mathrm{CO})_{4}$ & 55.35 & 255.78 & -13.37 \\
\hline
\end{tabular}

The M-C bond of the metal carbonyl models can be considered analogous to the interaction of CO with a metal surface. Bond dissociation energies (BDE's) of the metal carbonyls may indicate the relative affinities the metal surfaces have to adsorbing CO, the initial step in Fischer-Tropsch synthesis. The results from the metal carbonyl models suggest that the $\mathrm{CO}$ affinity for an iron surface is the strongest, relatively moderate for a cobalt surface, and weakest for a nickel surface. The results from the models containing cobalt carbonyl with Group IB metals suggest that the CO affinities increase with the size of the Group IB metal promoter. Using the BDE of carbon monoxide as the reference, the results indicate that all metals considered in this work weaken the $\mathrm{C}-\mathrm{O}$ bond. This effect can be considered analogous to the activation of the $\mathrm{C}-\mathrm{O}$ bond adsorbed on a metal surface.

As shown in Table 2, iron weakens the C-O bond to the largest extent, however, the effect that cobalt has is relatively substantial as well. Of the three metal carbonyls, nickel weakens the C-O bond the least. In comparison with $\alpha \mathrm{CoH}(\mathrm{CO})_{4}$, the results show that there is a further weakening of the $\mathrm{C}-\mathrm{O}$ bond with the addition of a Group IB metal in the cobalt carbonyl models. As shown in Table 3, the addition of gold has the largest effect and copper has the least. The trend suggests that the activation increases with increasing size of the Group IB metal.

The BDE of the metal-carbon bond (M-C) and the BDE of the carbon-oxygen bond (C-O) were determined using first principal calculations ( $\mathrm{ab}$ initio). The results from the metal carbonyl models indicate that the iron-carbon bond is the strongest, the cobalt-carbon bond is moderate, and the nickelcarbon bond is the weakest. In addition, the results indicate that all metals considered in this work weaken the $\mathrm{C}-\mathrm{O}$ bond, with iron having the greatest effect and nickel the least effect. Thus, there appears to be correlation between the strength of the $\mathrm{M}-\mathrm{C}$ and weakness of the $\mathrm{C}-\mathrm{O}$ bond. The results from the models containing cobalt carbonyl with Group IB metals indicate that the strength of the $\mathrm{M}-\mathrm{C}$ bond and the weakness of the $\mathrm{C}-\mathrm{O}$ bond increase with the size of the Group IB metal $(\mathrm{Au}>\mathrm{Ag}>\mathrm{Cu})$.

Considering the analogy of metal carbonyls as catalytic surfaces, the results suggest that an iron surface has the greatest affinity for $\mathrm{CO}$ and activates the $\mathrm{C}-\mathrm{O}$ bond the most. Cobalt is relatively moderate and nickel is the weakest for both affinity for $\mathrm{CO}$ and activation of the $\mathrm{C}-\mathrm{O}$ bond. Also, the results suggest that the addition of a promoter on a cobalt surface increases both the affinity for $\mathrm{CO}$ and the activation of $\mathrm{C}-\mathrm{O}$ bond, with gold providing the greatest increase.

\section{Materials Processing and Decomposition Studies}

The next several sections in this paper outline efforts to decompose polymer and biomass to extract fuel and commodity chemicals, either directly through pyrolysis (Polyflow Corporation) or indirectly via steam reforming (Pioneer Astronautics). We briefly describe efforts at NASA GRC to establish a chemical characterization and processing studies capability. The goal is to develop fundamental insights into decomposition of raw materials and novel green aerospace fuel production. A FTS catalyst production and characterization capability was described in a prior section. Current efforts are geared towards lower-temperature extraction of fuels from biomass and polymers and identification and removal of potentially harmful by-products from the combustion or pyrolysis of polymer and similar materials. Figure 10 shows a solvothermal reactor and a schematic of a catalytic transformation of biomass or polymers into aerospace fuels. 


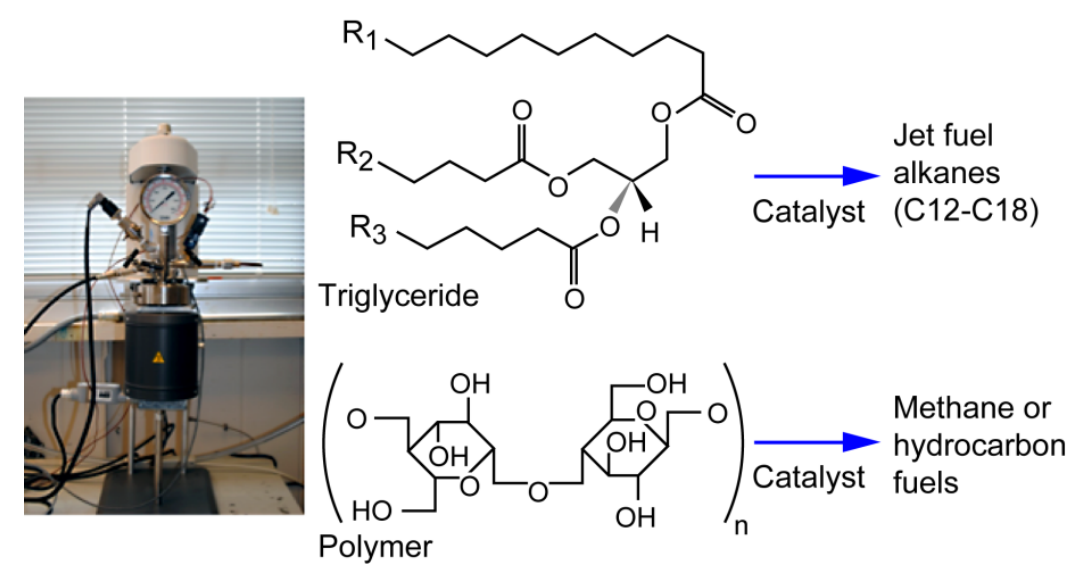

Figure 10.-Solvothermal reactor located in fuels processing facility in the Energy Conversion Lab at NASA GRC; green aerospace fuel synthesis.

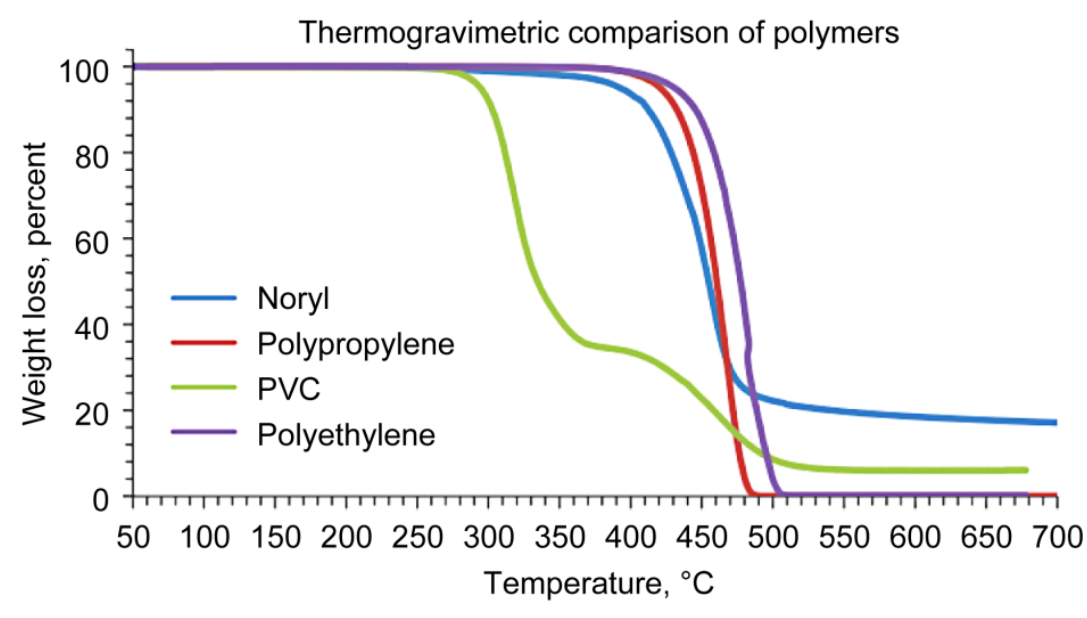

Figure 11.-Weight-loss data from thermogravimetric analysis (TGA) of four polymers; polyvinylchloride (PVC) decomposes at the lowest temperature.

Preliminary work at NASA GRC is underway to determine the impact of mixtures on the products of combustion or decomposition of a variety of polymer materials in the presence of metals, ceramics, and complex mixtures. This is relevant to processing of nonrecycled plastics and crew fire safety during flight. We are currently analyzing data from the decomposition of numerous polymers, these are typically in complex mixtures of materials of different types. Figure 11 compares the TGA of four well-known polymers. The polymer most readily decomposed, PVC, produces potentially hazardous chlorinecontaining by-products that must be removed through some means; see discussion below.

\section{Lunar Organic Waste Reformer Development}

The Lunar Organic Waste Reformer (LOWR) uses high temperature steam reformation to recycle waste paper, plastics, metabolic wastes and other carbon bearing wastes into valuable fuels and chemicals in support of long-duration space missions. During a Phase I SBIR program performed by Pioneer Astronautics for NASA GRC, the LOWR steam reforming technique was successfully used to convert solid organic materials into gases consisting primarily of hydrogen, carbon dioxide, and carbon monoxide. The carbon-containing gases were then converted to methane in a Sabatier reactor containing a ruthenium catalyst. The overall process results in the net production of oxygen and nearly pure methane in useful quantities. A high-temperature, sterile reaction environment ensures destruction of wastes while generating products that would otherwise require expensive delivery from Earth or production via more 
intensive ISRU methods. The LOWR also recovers water when feeding higher-moisture feedstocks. Water is extracted directly from wastes during steam reforming, thereby eliminating the need for a separate evaporation system.

During the Phase I program, wastes including high-moisture food residues, dog feces, plastics, paper, and charcoal were steam reformed. A slipstream of the reformer gas was fed to a Sabatier reactor, demonstrating integration of two key process steps involved in the LOWR. Up to 99 percent of the carbon-containing constituents of the gaseous reformer products were converted to methane. Efficient recovery methods were implemented during Phase I experiments to transfer heat from the high temperature reformer off-gas to superheat the steam used for reforming. The Phase I steam reformer was of sufficient size to accommodate up to $10 \mathrm{~kg}$ of waste per day when operated on a nearly continuous basis. Depending on the moisture content and chemical composition of the wastes, the LOWR can generate about $5 \mathrm{~kg}$ of methane and a roughly comparable amount of oxygen from $10 \mathrm{~kg}$ of waste.

The initial Phase I concept was aimed toward indirect steam reforming based on the use of solar thermal superheating of steam fed to the reformer. The resulting reformer gas was to be converted to a carbon monoxide product via a reverse water gas shift (RWGS) process (Ref. 1). The carbon monoxide could then be reacted with hydrogen to produce a suite of fuels or chemical products. After initial experimentation and systems analysis, an alternate approach was taken after consultation with NASA personnel. The alternate approach was sought due to the difficult operating conditions required for solar thermal steam superheating. The heat exchanger surfaces needed to be heated to or beyond the limits of most metallic alloys in order to provide the temperatures required for suitable reforming rates. The solar thermal method is also limited to the two-week lunar sunlight cycle, further restricting the operation of the LOWR. The alternate approach incorporates effective thermal heat recovery from the integrated system along with oxygen injection into the steam upstream of the reformer. Direct oxygen injection, resulting in auto thermal reforming, allowed for superheated steam in the $500{ }^{\circ} \mathrm{C}$ range to be used. Oxygen reacted at the surfaces of wastes in the reactor, generating high reforming rates at temperatures greater than $800{ }^{\circ} \mathrm{C}$ without damage to the hardware.

\section{Integration With a Sabatier Reactor}

The reformer exhaust was integrated with a Sabatier (Ref. 1) reactor to produce methane instead of carbon monoxide by RWGS. Methane has the advantage of being directly usable as a fuel in propellant and requires much less process gas recycle to generate a nearly pure product compared to carbon monoxide generation via RWGS. The Sabatier reaction requires supplemental hydrogen (produced from waste water by electrolysis). The electrolyzer is operated at a rate required to satisfy the methanation needs. An excess of oxygen results from the integrated operations after satisfying the hydrogen requirements. The overall system mass appears to be low relative to the production rate of methane and oxygen. Break-even would take only weeks to achieve. A wide variety of organic wastes can be processed in the LOWR using the flexible semibatch, down-flow reactor system. In one example, a single batch of waste is loaded into the steam reformer on a daily basis (with operations carried out over about $18 \mathrm{hr}$ of a $24 \mathrm{hr}$ day). Alternatively, wastes can be fed intermittently through a lock-hopper or other seal arrangement to allow for nearly continuous operation. The projected operations are conducted in a manner in which energy inputs are spread over time to reduce power requirements. Figure 12 shows a preliminary integrated Phase II flow sheet.

The reformer exhaust gas is passed through a series of heat exchangers (to provide superheating of the steam fed to the reformer as well as preheat of the water entering the boiler). The reformer exhaust is then passed through a condenser to remove water. The dry reformer gas is next passed through sulfur sorbent to remove any sulfur contaminants prior to introduction to the Sabatier reactor. Additional hydrogen is mixed with the dry reformer gas fed to the Sabatier reactor to drive the methanation reaction to completion. The exhaust gas from the Sabatier reactor is subjected to a series of heat recovery steps. The Sabatier exhaust gas is then condensed to remove water. The dry Sabatier gas is passed through a polymer membrane primarily to separate methane from hydrogen in order to generate a nearly pure methane product and hydrogen for recycle to the Sabatier reactor. 


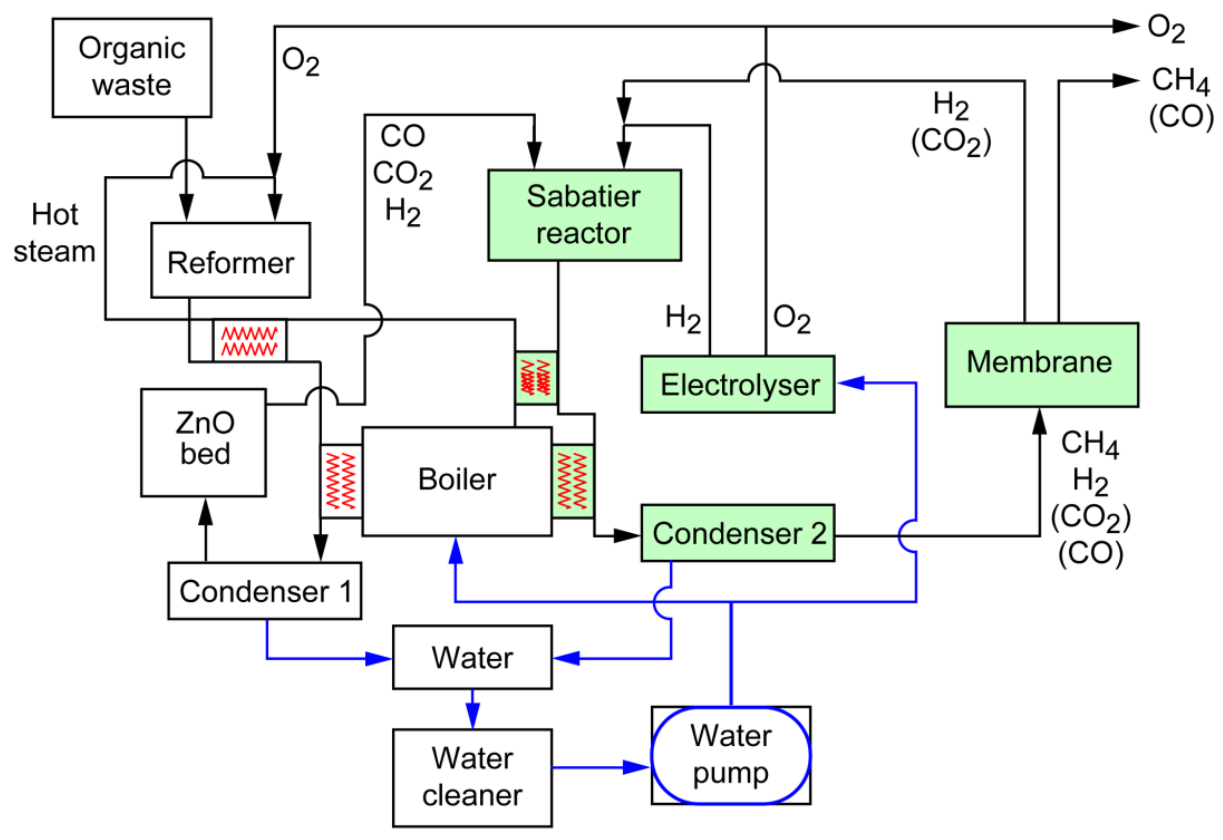

Figure 12.--Integrated LOWR-Sabatier block flow diagram.

Water in the reformer and Sabatier exhausts is cleaned to remove hydrocarbon impurities using activated carbon or comparable measures. A significant portion of the water is recycled to the reformer. Additional water is sent to an electrolyzer to generate the hydrogen make up needed for the Sabatier reactor. Oxygen produced concurrent with hydrogen is in part directed toward the reformer. Excess oxygen is collected as a product.

As shown in the diagram, significant efforts are taken to recover and reuse thermal energy from the reformer exhaust gas and the Sabatier exhaust gas (including its exothermic heat of reaction). Consideration of the overall process and potential contaminants are addressed in the preliminary design. Further refinements to the process and methodology are to be carried out as part of the Phase II development. Although the process is robust for processing a wide variety of wastes, some variation in the material balance and energy input result from the different potential feeds, ranging from low-moisture, high-carbon residues to high-moisture, volatile wastes.

Colored blocks in Figure 12 represent a proposed sequence of further development and implementation. White colored "Block 1" boxes represent an initial stage of implementation that can take place independent of green colored "Block 2" boxes. Block 2 boxes represent conversion of Block 1 reformer gas product to methane. Alternate down-stream technologies could be substituted for Block 2 (such as a RWGS system from generation carbon monoxide for syn-gas-based processes). Staged implementation allows for maximum flexibility during process development, dividing technology development requirements into tasks that can be addressed independently.

\section{Design of Phase I LOWR Unit}

The reactor design developed at Pioneer allows for occasional batch feed of wastes while generating a relatively steady exhaust gas rate at relatively steady gas composition after steam injection is started. Phase I experiments were generally carried out for periods of up to $2 \mathrm{hr}$. However, when operated almost constantly, the Phase I reactor is of the approximate size required to accommodate about $10 \mathrm{~kg}$ of waste per day, which is five times the stated Phase I goal and represents the target specified for the preliminary Phase II design. 


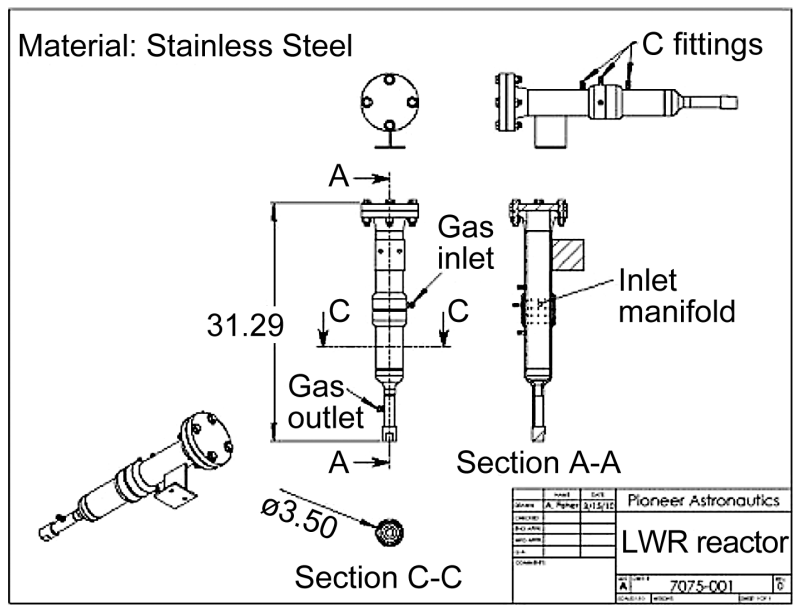

Figure 13.-LOWR reforming reactor drawings.

The power input is reduced and is more favorable when the energy input can be spread out over the longest time period. For continuous or nearly continuous operation, a reactor similar to that used in Phase I could be used with some additional provisions for repetitive, routine batch feeding. The Pioneer down-flow steam reformer is illustrated below. Waste is fed through the flange on the top of the reformer and flows down by gravity feed, to be consumed in the reaction zone located in the lower portion near the steam-oxygen injection plenum. The design of the LOWR reformer unit is shown in Figure 13.

The reactor shell was constructed from 3-in., schedule-10 stainless steel. The reactor is positioned vertically for use. A bolted flange is removed to load wastes into the reformer. A support at the bottom prevents losses of granular wastes. A containment cup can be incorporated into the reformer to allow plastics to be processed without melting, moving to colder regions, and causing plugs. As a result, wastes including polyethylene were successfully reformed. Overall carbon reforming rates of up to about $200 \mathrm{~g}$ per hour were achieved in the Phase I unit. A provision for manual removal of ash from the bottom of the reactor was made in the Phase I design. A plenum was fabricated to inject steam (and oxygen) into the bed of waste material.

\section{LOWR Test Results}

As discussed in the previous section, an initial plan called for using superheated steam that was heated outside the unit in preparation for injection through the steam plenum. Experiments led to design revisions that still used steam injection through the plenum, but steam was supplemented with oxygen to provide the internal reactor temperatures needed to support relatively quick reforming rates without the need to superheat the steam beyond the limits of steel construction.

A photo of the complete Phase 1 LOWR system in operation is shown in Figure 14; the boiler which generates steam is the small insulated vessel on the left, the reformer reactor is the large insulated vessel in the upper center, and the Sabatier reactor is the small copper-foil wrapped vessel in the lower center.

The output of the reformer using a variety of feedstocks over a number of test runs is given in the first four columns of Table 4 . The outputs were then reacted with hydrogen in a one-pass Sabatier reactor to achieve the methane conversions (percent of methane as a fraction of all carbon-bearing gases shown in the right hand column of Table 4. It can be seen that high methane conversions were readily achieved, even in such a simple one-pass system. If recycle of un-reacted $\mathrm{CO}$ and $\mathrm{CO}_{2}$ were done, virtually complete conversion could be achieved. 


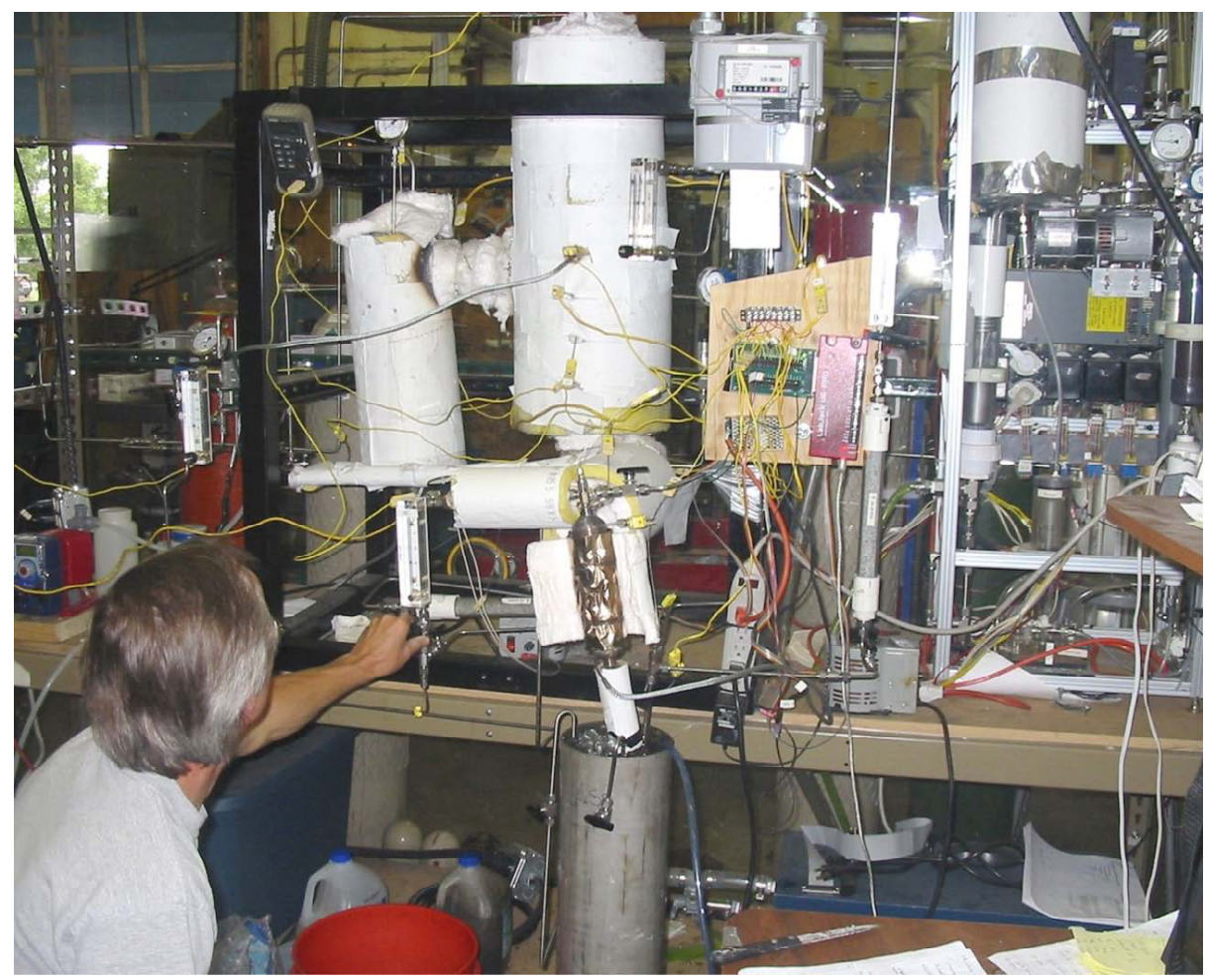

Figure 14.-Picture of integrated LOWR-Sabatier system during operation.

TABLE 4.-REFORMER EXHAUST GAS COMPOSITIONS AND PEAK SABATIER CONVERSIONS

\begin{tabular}{|l|c|c|c|c|c|c|}
\hline \multirow{2}{*}{ Date } & \multicolumn{6}{|c|}{$\begin{array}{c}\text { Reformer output composition, } \\
\text { vol\% }\end{array}$} \\
\cline { 2 - 7 } & $\mathrm{H}_{2}$ & $\mathrm{CO}$ & $\mathrm{CO}_{2}$ & $\mathrm{CH}_{4}$ & Feed & $\begin{array}{c}\text { Sabatier conversion, } \\
\text { percent }\end{array}$ \\
\hline June 30 & 46 & 11 & 41 & 2 & Biomass & 94.2 \\
\hline July 2 & 46 & 19 & 34 & 1 & Biomass & 98.4 \\
\hline July 7 & 49 & 12 & 37 & 2 & Biomass & 81.7 \\
\hline July 8 & 49 & 13 & 36 & 2 & Biomass & 99.0 \\
\hline July 13 & 45 & 11 & 39 & 5 & Biomass & 98.3 \\
\hline July 15 & 44 & 15 & 39 & 2 & Biomass & 98.4 \\
\hline July 20 & 34 & 14 & 48 & 4 & Plastic & 98.0 \\
\hline July 22 & 37 & 16 & 41 & 6 & Plastic & 98.7 \\
\hline
\end{tabular}

In Phase I experiments, extra $\mathrm{H}_{2}$ needed by the Sabatier reactor was drawn from gas bottles. In a flight system, it would be produced by electrolysis of water, which typically constitutes a large fraction of bio-wastes. Oxygen is thus produced by the process at the same time. Such an end-to-end system producing both fuel and oxygen from wastes will be demonstrated in Phase II of the LOWR program. Sample system results are shown in Figure 15.

The LOWR was conceived to meet the needs of NASA's lunar base program while reducing the amount of consumables that need to be transported to the Moon. The LOWR can be a key component of the lunar exploration program by allowing available power sources to enable production of oxygen and fuel on a sufficient scale to significantly reduce Lunar base logistic requirements. The LOWR is not limited to Lunar applications, however. It can also be used on the Martian surface, or on any long duration piloted spacecraft, including the International Space Station or any deep space crewed vehicle used for example on human missions to Near Earth asteroids or Mars. 


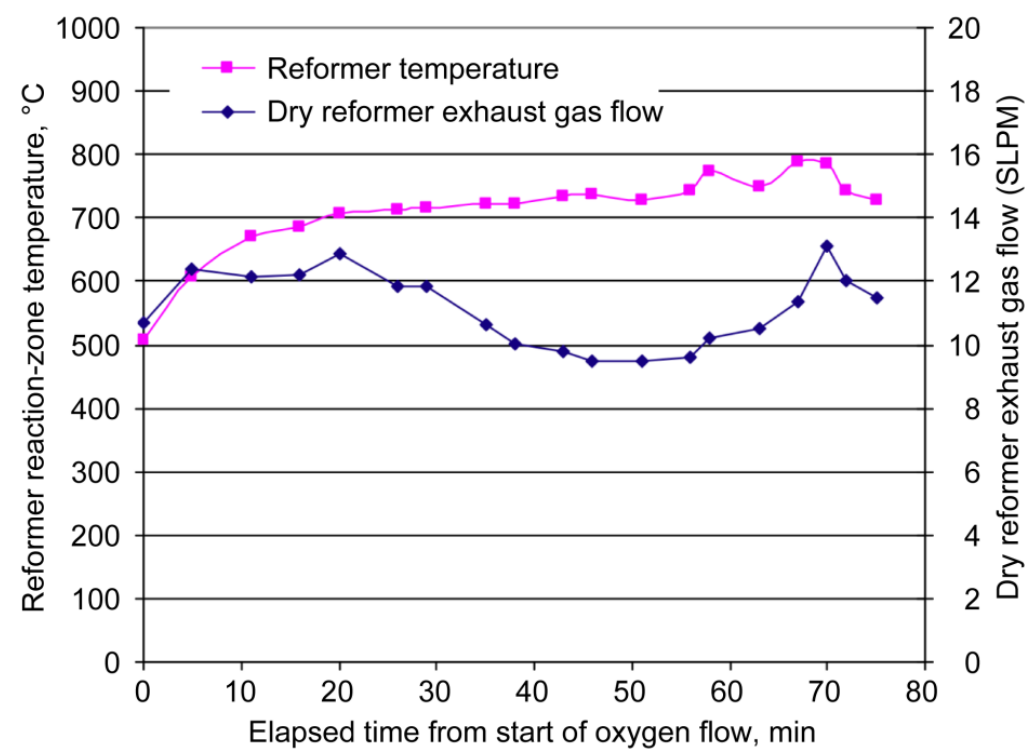

Figure 15.-Temperature and reformer exhaust gas profile (7-8-10).

\section{Polymer Pyrolysis Process Development for Transportation Fuel and Chemicals Production}

Polyflow LLC of Akron, Ohio is developing a pyrolysis process to directly convert polymer waste into fuels and aromatic precursor chemicals. A pilot plant was built (Fig. 16) and run for several years to further develop the technology. The results discussed in this paper are taken from sample product produced with several equipment designs, process parameters, widely varying operating conditions and a broad range of feedstock materials and feedstock composition and inert content. The overall goal was the validation of the Polyflow process parameters in a production-scale processor. The patent-pending Polyflow chemistry claims the production of aromatic chemicals and fuels from mixed and contaminated polymer feedstock. The preliminary data demonstrates that Polyflow has developed an extremely robust process.

\section{Feedstock and Process}

The feedstock was separated, identified and weighed ahead of time. For most runs the feedstock composition matched the Environmental Protection Agency (EPA) data for the polymer waste stream going into landfills daily. Because the feedstock was not shredded, most runs had a load of 200 to $300 \mathrm{lb}$, limited by the volume of the reactor vessel. The reactor was loaded early in the morning, heated and run through early afternoon, 4 to $5 \mathrm{hr}$. The temperature and pressure were recorded regularly. The product was collected, weighed and samples were drawn at set intervals, giving a rate of production and samples for analysis throughout the run. The light noncondensable off-gas was sampled two or three times during the run. Some samples were taken before the scrubber and some after. The reactor was allowed to cool overnight and opened the next day to remove the char. The char was weighed and samples taken for coal analysis. For several samples, an analysis of the Resource Conservation and Recovery Act (RCRA), administered by the U.S. EPA, metals and heteroatom content was completed. Occasionally, a master composite sample composed of product of several runs was analyzed to provide average data.

The feedstock was selected to match the composition of the polymer waste stream flowing into the landfill daily. This composition closely matches the polymer production data provided by the polymer industry associations. Polyflow acquired feedstock through a variety of methods. Plastic trash was brought in by company employees, local businesses and community organizations contributed materials, construction waste materials were donated, tire chips were purchased, carpet waste was donated, and 


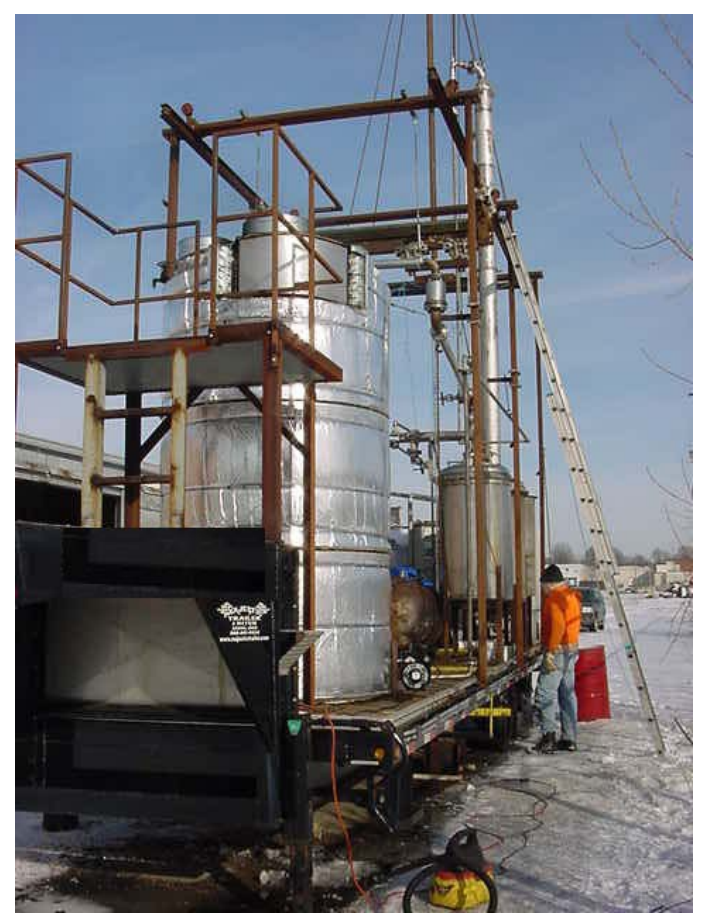

Figure 16.-Polyflow pilot-scale processor.

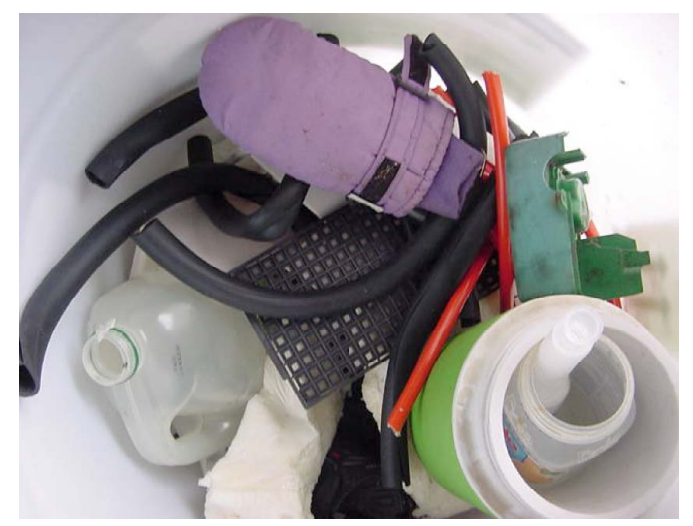

Figure 17.--Industrial waste materials and miscellaneous \#7 plastic feedstock.

special interest plastic waste was provided by industrial partners including computer parts, toner cartridges, powdered paint, and food packaging (see Fig. 17 for representative sample). The standard feedstock composition was modified with the special interest items by removing feedstock of like polymer type and adding the special interest feedstock. Several runs were modified by eliminating the feedstock having a high-filler content to gain understanding of the impact of fillers. Specific runs were spiked with high amounts of nylon, PVC, and brominated materials.

During the campaign, the process was adjusted to determine the acceptable range of the process variables for the design of the next generation reactor. These adjustments included: temperature of the reactor; reaction pressure; agitation; rate of heat input; and condenser temperature. In addition to these controlled process parameters, ambient temperature varied from sub-freezing winter conditions to over $90^{\circ} \mathrm{F}$ summer days; feedstock had the natural variation of a waste stream. At higher batch sizes, feedstock was shredded to enable filling the reactor. 


\section{Liquid, Gas, and Solid Analysis Results}

Liquid product samples were analyzed by Gas Chromatograph-Mass Spectroscopy in the Analytical Chemistry Lab at Baldwin Wallace College. These samples included sequential samples taken during the run and a composite sample consisting of the total product made during one run. Usually five to fifteen peaks were identified. Calibration standards of benzene, toluene, ethylbenzene, styrene and cumene were measured to provide for better than a rough estimate, these aromatics are the most valuable fraction for resale as a commodity chemical. Other identified materials typically consisted of olefins and paraffins in the $\mathrm{C}_{8}$ to $\mathrm{C}_{20}$ range. Samples from several runs were analyzed at Crystal Laboratories for impurity content; results for liquid and off-gas are presented in Table 5.

The noncondensable off-gas was sampled using stainless steel sample vials, usually before scrubbing, but on occasion after scrubbing. These samples were analyzed for combustible constituents as well as sulfur, bromine, chlorine, and nitrogen. The gas composition presented in Table 6 is typical.

The solid by-products (also called char) were sampled after large pieces of metal, glass and other pieces of inert materials had been removed. The analysis was completed by Crystal Laboratories and consisted of tests normally run on coal, a Proximate Analysis and an Ultimate Analysis. The ash was also analyzed for RCRA metals including zinc. The mass data in this report on contaminants and char volume include the large metal and other inert material pieces (glass, stones, wire, nuts, bolts, screws, aluminum foil, copper wire, etc.) in the char. The typical content of the solid by-product was 91 percent ash, 4 percent moisture, 2.5 percent carbon, and the 2.5 percent balance was nitrogen, hydrogen, sulfur, and oxygen, in that order.

TABLE 5.-SIGNIFICANT METAL AND HETEROATOM IMPURITIES OF ANALYZED LIQUID FRACTION

\begin{tabular}{|l|c|c|}
\hline \multicolumn{1}{|c|}{ Element } & $\begin{array}{c}\text { Liquid result, } \\
\text { PPM }\end{array}$ & $\begin{array}{c}\text { Off-gas result, } \\
\text { PPM }\end{array}$ \\
\hline Bromine $(\mathrm{Br}, \mathrm{HBr})$ & 397 & 34 \\
\hline Calcium $(\mathrm{Ca})$ & 148 & ----- \\
\hline Chlorine $(\mathrm{Cl}, \mathrm{HCl})$ & 168 & 67 \\
\hline Iron + Aluminum $(\mathrm{Fe}, \mathrm{Al})$ & 67 & ----- \\
\hline Nitrogen $(\mathrm{N})$ & 161 & ----- \\
\hline Sulfur $\left(\mathrm{S}, \mathrm{H}_{2} \mathrm{~S}, \mathrm{CS}_{2}\right)$ & 790 & 3066 \\
\hline Silicon $+\mathrm{Phosphorus}(\mathrm{Si}, \mathrm{P})^{\text {Pinc }(\mathrm{Zn})}$ & 73 & ----- \\
\hline
\end{tabular}

TABLE 6.-NONCONDENSABLE OFF-GAS CONSTITUENTS

\begin{tabular}{|l|c|l|}
\hline \multicolumn{1}{|c|}{ Functional group or type } & Carbon range & \multicolumn{1}{c|}{ Compounds } \\
\hline Simple low-mass inorganic compounds & 0 to 1 & $\mathrm{O}_{2}, \mathrm{CO}_{2}, \mathrm{H}_{2}, \mathrm{CO}, \mathrm{H}_{2} \mathrm{O}$ \\
\hline Paraffins or saturated hydrocarbons & 1 to 4 & Methane, Ethane, Propane, Butanes \\
\hline Olefins or unsaturated hydrocarbons & 2 to 5 & Ethene, Propene, Butene, Pentene \\
\hline Polyenes or poly-unsaturated hydrocarbons & 4 to 5 & 1,3-Butadiene 1,3-Pentadiene, Isoprene \\
\hline Aromatic hydrocarbons & 6 to 8 & $\begin{array}{l}\text { Benzene, Toluene, Ethylbenzene, Xylenes, } \\
\text { Styrene, Cumene, Methylstyrene }\end{array}$ \\
\hline
\end{tabular}




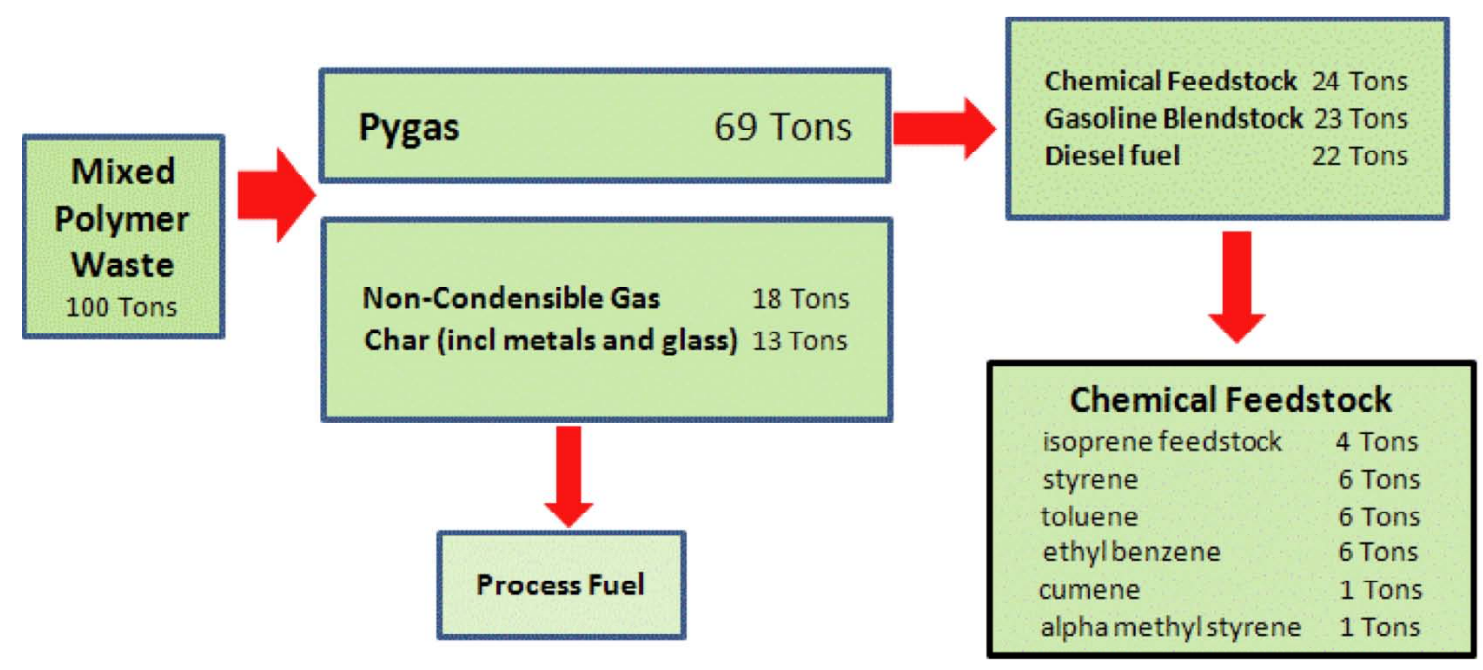

Figure 18.-Mass balance of a theoretical 100 tons of mixed polymer waste using analysis results averaged over a recent processing campaign at Polyflow. Pygas is the hydrocarbon product.

\section{Process Issues, Products, and Discussion}

During the pilot plant campaign, over nine tons of polymer waste was processed and over 1675 gal of liquid product produced. The runs included many differing process conditions, equipment configurations and feedstocks as process tolerances and its repeatability were explored to develop design data for the next generation processor. The feedstock, liquid and char were weighed and the noncondensable gas was calculated by difference. For runs where the inerts were minimized, liquid yields over 80 percent (liquid produced to total waste loaded) were achieved. Analysis of yields enables us to predict, using EPA polymer waste composition, a product yield of 69 percent. This includes the isoprene currently in the off-gas. This is 4.8 barrels of liquid per ton of polymer waste. The char (inerts) averaged 13 percent of the feedstock and consisted primarily of clay and calcium fillers, glass fiber reinforcements, and carbon black fillers from the tires and metal pieces. Tire wire and other metals were removed by magnetic separation. The aluminum, including the very thin flash coating from potato chip bags, was picked out by hand as much as practical. A rough overall mass balance is shown in Figure 18.

The Polyflow energy balance relies upon the EPA's published energy content of municipal waste polymers, natural gas, gasoline and diesel fuel and is confirmed by the fuel used during the demonstration campaign. The waste polymer energy content is taken from the EPA's waste-to-energy data and we have backed out the assumed burner efficiencies to get the total energy content. The pyrolysis gasoline (or pygas) is calculated as a weighted average of the mixed aromatics, gasoline, and diesel fuel. The process fuel is calculated from the heat required during the demonstration run for the reactor with additional amounts for the planned separations. The char is as measured at Crystal Laboratories, $3000 \mathrm{BTU} / \mathrm{lb}$, or about one-third of that of coal, because of its over 90 percent ash (clay, glass, and other in-organics) content. The off-gas is calculated by mass difference. Off-gas energy nearly satisfies the Polyflow plant requirements. If in production there is excess gas, Polyflow would contemplate using the excess to generate electricity for the plant and for sale to the grid. The energy balance is shown in Figure 19.

Data from the demonstration campaign shows that 13.3 percent of the mixed polymer waste processed is inert fillers and is in the char. These inert materials consist of carbon black and wire from the tires, calcium fillers from the carpet and other polymers, glass fiber reinforcements, paper labels, aluminum packaging film, screws and EMI/RFI shielding materials from e-waste, fire retardants, plasticizers, curing agents, talc, clay food, gypsum, dirt, etc. A portion of the bromine, chlorine and nitrogen end up in the liquid. $\mathrm{HCl}$, generated from the PVC in the waste stream, ends up in the off-gas. Metallic materials 


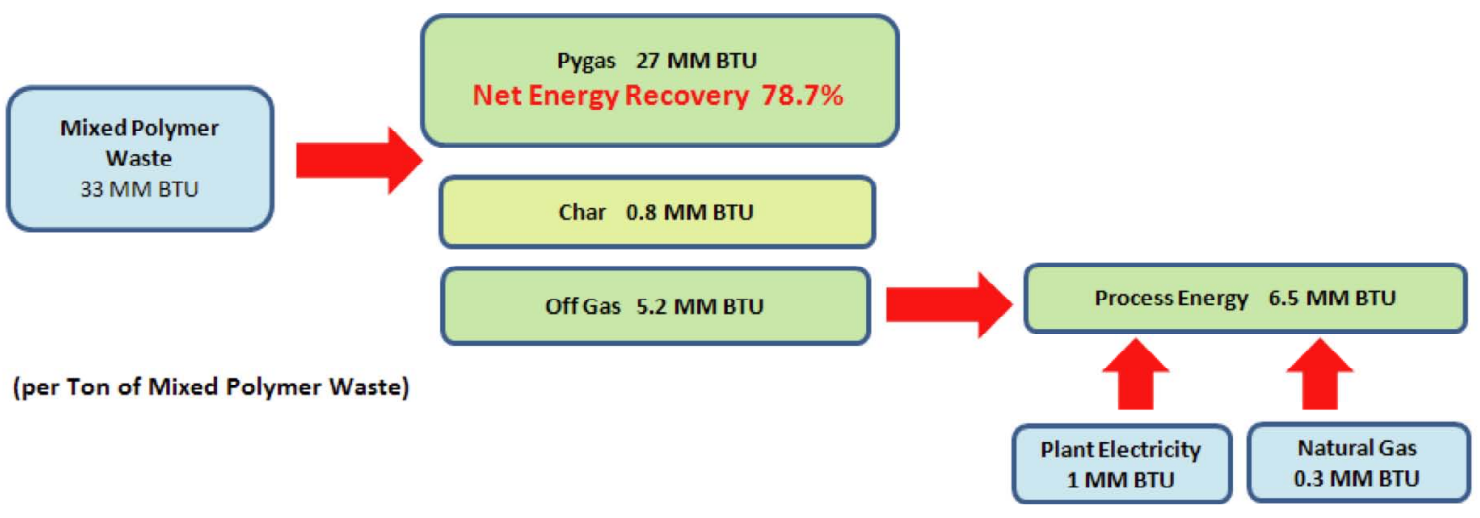

Figure 19.-Energy balance from a recent Polyflow campaign per ton of mixed polymer process waste. Note that MMBTU is millions of BTUs. Burning of off-gas would supply 80 percent of the process energy needs.

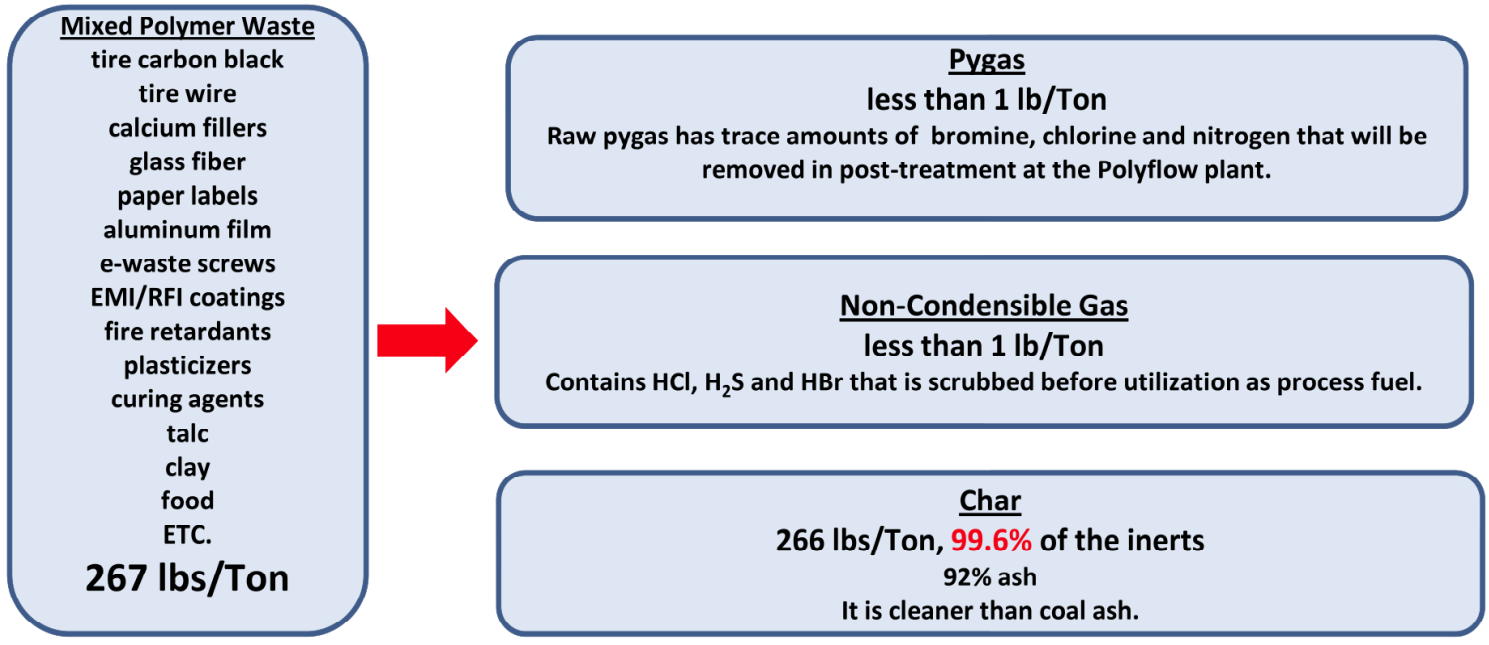

(per Ton of Mixed Polymer Waste)

Figure 20.-Mass balance of inert materials per average Polyflow processing run. Note that a very large fraction (>99 percent) of the inert ends up in the solid waste (or char).

overwhelmingly end up in the char. The resulting balance is that for the total $267 \mathrm{lb}$ of inerts per ton of feedstock, 99.6 percent of these are in the char, 0.03 percent in the gas and 0.37 percent in the liquid product. The mass balance of the inert materials is shown in Figure 20.

The standard EPA polymer waste going to the landfill contains 17.86 percent aromatics. The average aromatic content of all of the 2008 pilot plant campaign runs is 22.1 percent, counting only the eight identified and separable aromatics. A ${ }^{13} \mathrm{C}$ NMR analysis on the July 2008 demonstrations indicated 38 percent aromatics. As discussed above, this is the most profitable fraction of the Polyflow process. In nearly every run, Polyflow increased the aromatics count in product versus the EPA average. A yield summary of the 2008 Pilot Plant Campaign of identifiable aromatics is shown in Figure 21.

Polyflow can convert mixed and contaminated polymer waste into high-octane gasoline, diesel fuel and chemical feedstock at high yields. Polyflow produces a high level of aromatics and chemical feedstock. The Polyflow process is very robust in process conditions and feedstock composition. The Polyflow process is energy efficient. The Polyflow process has a minimal carryover of inert materials to the products. The Polyflow off-gas is nearly as clean as natural gas. The Polyflow char is as clean as coal and is land-fillable as is the ash from burning the char. 


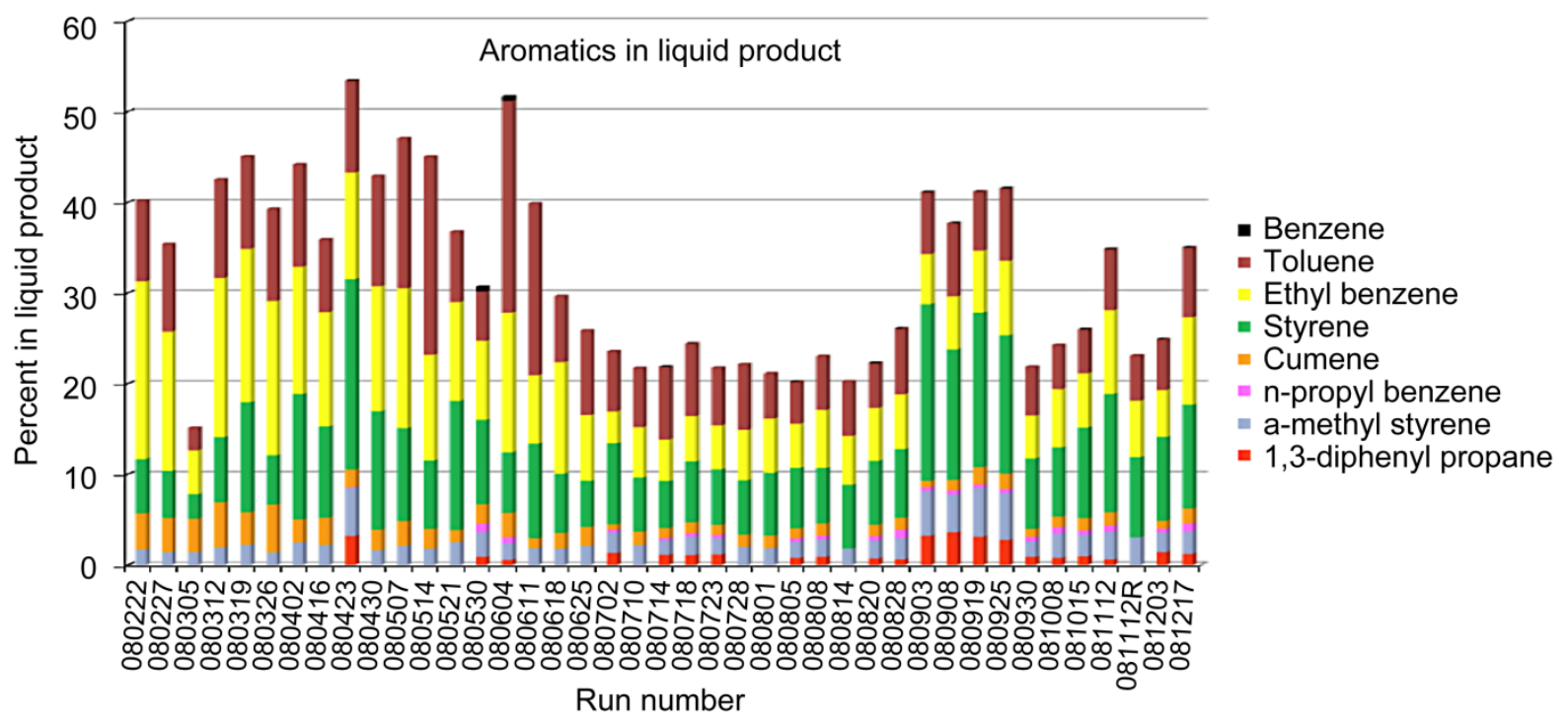

Figure 21.-Yield of identifiable aromatics during 2008 campaign.

\section{Removal of Unwanted Species From Green Aerospace Fuels}

There is a heightened interest in developing green and ultra-clean fuels driven by advances in new emissions control technologies for engines including those for aerospace and vehicular systems such as internal combustion, diesel, and fuel cells. The removal of unwanted species including $\mathrm{Cl}, \mathrm{S}$, and $\mathrm{F}$ components from process streams such as green aerospace fuels is necessary to prevent deleterious reactions in down-stream process units. For instance, sulfur compounds including hydrogen sulfide and sulfur dioxide can interfere with engine materials degrading them or affect catalytic processes via sulfur catalyst poisoning. In work for NASA, Reactive Innovations is developing an $\mathrm{H}_{2} \mathrm{~S}$ and $\mathrm{SO}_{2}$ removal system to selectively remove these compounds from lunar regolith process streams as a part of the in situ resource utilization efforts to fabricate habitats on the lunar surface.

\section{Technology Approach}

Reactive Innovations is under contract to NASA to develop and deliver a compact and lightweight electrochemical reactor to separate hydrogen sulfide and sulfur dioxide from regolith process streams for NASA's lunar habitation outpost. Reactive has previously demonstrated a reactive-separation process where a redox carrier selectively binds to the sulfur compounds allowing them to be removed through an ionic liquid imbibed membrane separator. This process electrochemically pumps the bound sulfur compounds across a membrane separator effectively concentrating the sulfur compounds into a separate process stream. Reactive's approach builds on recently developed technology in its laboratory and others in selective separation based on electrochemically modulated facilitated transport through task-specific ionic liquids. Unlike conventional membrane and absorption schemes, Reactive's approach selectively binds the sulfur compounds via charge transfer mechanisms to redox carriers. This allows the separator system to transfer the bound sulfur compounds through a membrane where they are subsequently released freeing the redox molecule to repeat the process. With this approach, no regeneration step is required for this membrane allowing a continuous process to occur for removing sulfur from the process streams by applying a potential across the membrane.

Reactive's proposed approach can be viewed as an advanced hybrid membrane/absorption technology. The technology is electrochemically-facilitated transport of sulfur compounds bound to a redox carrier. Similar mechanisms are under development for gaseous $\mathrm{CO}_{2}$ separation that selectively binds to a redox species that Reactive previously demonstrated in a NASA program (Refs. 18 and 19). 


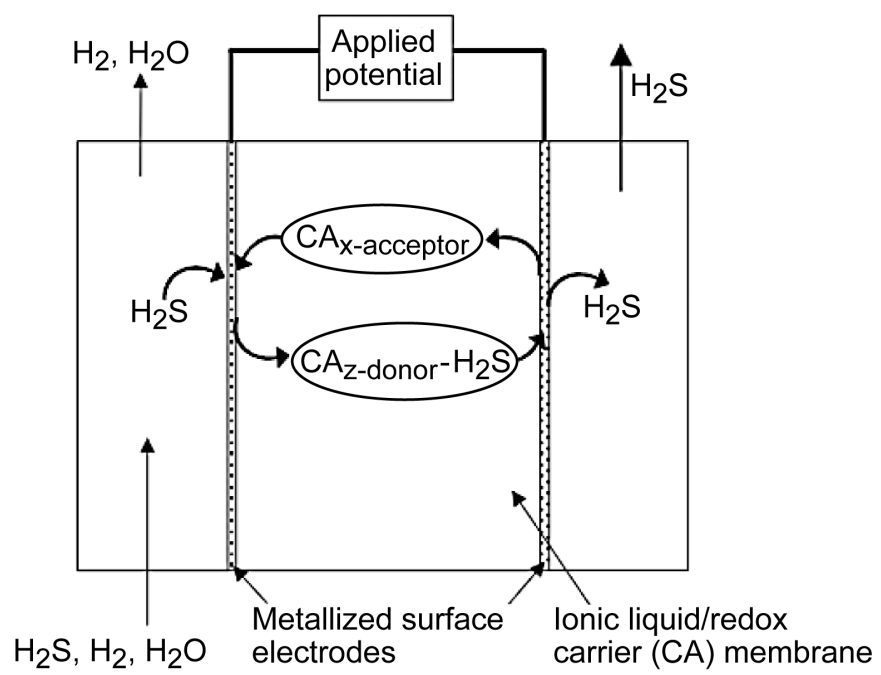

Figure 22.--Schematic for sulfur compound removal from process streams via electrochemical transport.

Ionic liquids are essentially room temperature molten salts, which when supported are physically similar to a solid membrane, insensitive to orientation with a negligible vapor pressure. Figure 22 shows a schematic of the facilitated transport process. In this approach, a sulfur compound such as $\mathrm{H}_{2} \mathrm{~S}$ or $\mathrm{SO}_{2}$ forms a charge-transfer complex with a redox molecule (such as 4,5-dicyano-2,7-dinitrofluorenone) that is immobilized within an ionic liquid imbibed membrane separator. A small potential $(<1 \mathrm{~V})$ is applied across the electrochemical cell, this facilitates binding sulfur on one side of the cell and releasing it on the other side. This process lends itself to an effective method for removing sulfur from process streams forming separated streams of $\mathrm{H}_{2} \mathrm{~S}$ or $\mathrm{SO}_{2}$ that can subsequently be used in other process streams.

The immobilized ionic liquid membrane embodies metallic electrodes deposited on both sides to form a membrane and electrode assembly (MEA). These electrodes can function catalytically, but mainly serve as electron donor and acceptor current collectors. Thus, metals can be selected that have known corrosion resistance to hydrogen sulfide that include tantalum, molybdenum, tungsten, aluminum, and magnesium. Since most ionic liquids are stable over voltage windows of approximately $4 \mathrm{~V}$ and have conductivities in the range of $0.1 \mathrm{mS} / \mathrm{cm}$, the imbibed ionic liquid is responsible for transferring the redox carrier between the electrodes in the MEA.

\section{Performance of Membrane and Electrode Assembly}

Several advantages are inherent in the use of a membrane and electrode assembly (MEA) as depicted in Figure 22. First, the use of an imbibed ionic liquid membrane allows for substantial tunability in the absorption/desorption properties of sulfur compounds in the process streams excluding the $\mathrm{H}_{2}$ and $\mathrm{H}_{2} \mathrm{O}$ or $\mathrm{O}_{2}$ and $\mathrm{H}_{2} \mathrm{O}$ constituents. Prior precedence for this work has been conducted by Zhang et al. (Ref. 20) showing extractive desulfurization in fuels using ionic liquids based on 1-alkyl-3-methylimidazolium $(\mathrm{MIM})$ and either tetrafluoroborate $\left(\mathrm{BF}_{4}\right)$ or hexafluorophosphate $\left(\mathrm{PF}_{6}\right)$ as well as trimethylamine hydrochloride $\left(\mathrm{AlCl}_{3}-\mathrm{TMAC}\right)$. Other ionic liquids showed a range of selectivities for sulfur including [ethyl-MIM] [BF 4 ], [propyl-MIM] $\left[\mathrm{PF}_{6}\right]$, and [butyl-MIM][BF 4 (Refs. 21 to 23).

Regeneration steps have to be used with these ionic liquids making their use limited for continuous processing unless multiple beds are used. By incorporating a redox carrier in an ionic liquid, Reactive's separation process overcomes this regeneration step by continuously binding and releasing the sulfur compounds using the ionic liquid as a benign ionic carrier. This is illustrated in Figure 23 shown by a cyclic voltammetric scan in an ionic liquid and redox carrier system, the reference electrode was $\mathrm{Ag} / \mathrm{AgCl}$. A nitrogen background stream was first assessed in the separator showing no significant redox 


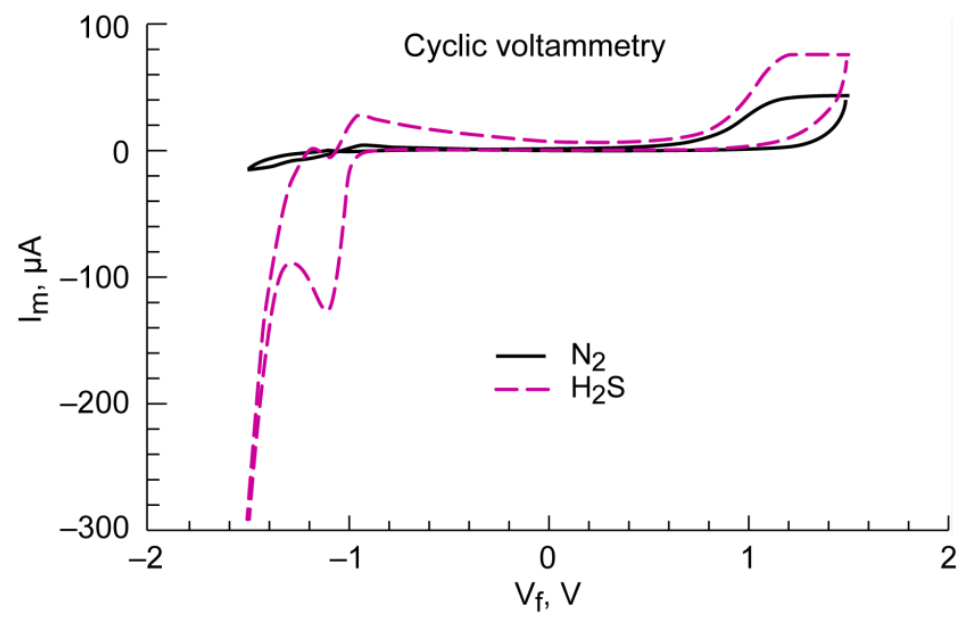

Figure 23.-Cyclic voltammetric scan for removing $\mathrm{H}_{2} \mathrm{~S}$ in an ionic liquid and redox carrier electrolyte.

behavior as shown in Figure 23. However, for a $100 \mathrm{ppm}_{2} \mathrm{~S}$ stream, a reversible redox behavior is shown for the binding and subsequent release of $\mathrm{H}_{2} \mathrm{~S}$ in the system. Thus, this facilitated transport process can selectively remove $\mathrm{H}_{2} \mathrm{~S}$ by electrochemically binding and releasing the molecule across a separator.

To conduct a selective separation process for sulfur, it is necessary to apply the ionic liquid/redox carrier to a platform capable of handling high flow-rate gas streams. Reactive Innovations, LLC has developed a compact and lightweight tubular-shaped reactor and separator platform that is ideal for processing high flow-rate streams. This electrochemical reactor is an array of miniaturized tubular MEAs that are packaged into a cylindrical reactor housing. This approach was used by Reactive to develop and deliver a water electrolyzer to NASA containing an array of 30-tubular cells for high-pressure (e.g., $3000 \mathrm{psi}) \mathrm{H}_{2}$ and $\mathrm{O}_{2}$ production for use in future NASA lunar base operations. Tubular plug-flow reactor designs are well suited for high-throughput, low pressure-drop flow for processing chemical streams since multiple tubular MEAs can be installed in parallel.

High flow rates can be maintained through the assembly while still maintaining intimate contact of the process gas streams with the large surface areas of the MEA allowing the sulfur compounds to be extracted. With this reactive-separation process, development of other ionic-liquid and redox carrier electrolytes is under development to remove unwanted species included $\mathrm{NO}$ and $\mathrm{NO}_{\mathrm{x}}$. Applications of these ionic liquid electrolytes immobilized in a membrane separator and applied in Reactive's tubular electrochemical reactor can selectively remove unwanted species in high flow rate systems.

\section{Impurity Species: Issues and Opportunities}

The issues around unwanted chemical species from processing petroleum and coal are well known and helped to motivate a search for alternative fuel technologies such as FTS (Refs. 1 to 3) as discussed above. Halogen $(\mathrm{F}, \mathrm{Br}$, and $\mathrm{Cl})$ compounds have been implicated in numerous health and environmental issues, such as ozone depletion. The same basic issues arise from $\mathrm{S}$ and $\mathrm{N}$ compounds and metal byproducts. There is a significant worldwide effort underway to capture and/or mitigate the impact of the by-products of fossil fuel processing. The same concerns are relevant for such by-products from processing regolith, recycled materials, or other nonpetroleum feedstocks. Polyflow has taken great care in removing impurity species from the products and confining them to the solid waste or char that comprises approximately 13 percent of the total output from their process. Table 7 summarizes the expected impurity species to be derived from processing a representative selection of common polymer materials. It is clear that hetero-atoms (that become impurity species) are a significant fraction of the total mass of polymer materials. While heavier atoms, typically metals, are relatively easy to separate out, volatile materials deriving from $\mathrm{S}, \mathrm{N}$, and the halogens continue to be a challenge hence the emphasis on removing these species (Refs. 20 to 23 ). 
TABLE 7.-SOURCES OF IMPURITY SPECIES FROM POLYMER FEEDSTOCKS

\begin{tabular}{|l|c|c|c|}
\hline \multicolumn{1}{|c|}{ Polymer } & Monomer & Impurity element (Compound(s)) & Weight percent \\
\hline Polytetrafluoroethylene & $\mathrm{C}_{2} \mathrm{~F}_{4}$ & Fluorine $\left(\mathrm{F}_{2}, \mathrm{HF}\right)$ & 75.98 \\
\hline Polybrominatedbiphenyl & $\mathrm{C}_{12} \mathrm{H}_{10} \mathrm{Br}_{2}$ & Bromine $\left(\mathrm{Br}_{2}\right)$ & 50.91 \\
\hline Polyvinyl chloride & $\mathrm{C}_{2} \mathrm{H}_{4} \mathrm{Cl}$ & Chlorine $\left(\mathrm{Cl}_{2}, \mathrm{HCl}\right)$ & 55.86 \\
\hline Polyurethane & $\mathrm{C}_{17} \mathrm{H}_{16} \mathrm{~N}_{2} \mathrm{O}_{4}$ & Nitrogen $(\mathrm{N})$ & 8.97 \\
\hline Polysulfone & $\mathrm{C}_{27} \mathrm{H}_{22} \mathrm{O}_{4} \mathrm{~S}$ & Sulfur $\left(\mathrm{S}, \mathrm{SO}_{2}, \mathrm{H}_{2} \mathrm{~S}, \mathrm{CS}_{2}\right)$ & 7.25 \\
\hline Polydimethylsiloxane & $\mathrm{C}_{2} \mathrm{H}_{6} \mathrm{OSi}$ & Silicon $(\mathrm{Si})$ & 37.91 \\
\hline
\end{tabular}

Another reason for separating sulfur compounds from regolith is to capture the hydrogen sulfide and use it to reduce iron, calcium, and magnesium oxide in the Lunar (or Martian) regolith using a high temperature thermal decomposition process (Refs. 24 and 25). In this approach, a stream of $\mathrm{H}_{2}, \mathrm{H}_{2} \mathrm{O}$, and $\mathrm{H}_{2} \mathrm{~S}$ is produced where the water can be electrolyzed to form hydrogen and oxygen. If the hydrogen sulfide is removed before the electrolyzer, then a separation process needs to remove $\mathrm{H}_{2} \mathrm{~S}$ from $\mathrm{H}_{2}$ and $\mathrm{H}_{2} \mathrm{O}$; if the sulfur compound is removed after the electrolyzer, then the $\mathrm{H}_{2} \mathrm{~S}$ is converted to $\mathrm{SO}_{2}$ during electrolysis that needs to be removed from $\mathrm{O}_{2}$ and $\mathrm{H}_{2} \mathrm{O}$. These sulfur compounds must be removed to eliminate downstream contamination of equipment and sulfur toxicity related issues with oxygen used in environmental systems. In general, whenever attempting the processing of any waste, sulfur emissions from landfills or waste water processing, sulfur processing will be problematic in a similar manner as in processing regolith; an efficient method is needed to remove and possibly recycle the sulfur (or other) components.

\section{Conclusions}

Clearly there are different issues surrounding nonpetroleum feedstocks for aviation and terrestrial transportation fuels and ISRU processing of fuels to contribute to space exploration. However, whether the feedstocks for green aerospace fuels are syn-gas, recycled polymers, metabolic waste, or bio-mass, common concerns to be addressed include: elimination and handling of (hazardous) by-products, energy efficiency and utilization, processing equipment reliability, overall cost effectiveness, and suitability for or integration into a particular mission or application. Since ISRU is inherently a "green approach" to space exploration, terrestrial utilization of resources and energy can be enhanced by adapting new technologies developed for the challenges of the Moon, Mars, and beyond. For example, solar energy utilization could perhaps preclude reliance on nonrenewable energy for the Polyflow Process making it "carbon neutral" in reference to the grid or fossil fuels. Developing workable processes for utilizing waste sulfur or other by-products from waste utilization on Earth could be adapted to ISRU and eventually used to tap into extra-terrestrial mineral resources such as those found on the Moon, Mars, asteroids, or eventually, moons of the gas giants. We began this paper with an overview of feedstock processing. If humanity is to rationally design and approach a long reach into the solar system, a firm grasp of fundamentals like $\mathrm{C} 1$ chemistry and energy efficiency will be essential for efficiently exploiting resources such as Saturn's moon Titan, which is literally a cryogenic hydrocarbon storage depot.

\section{References}

1. Peña, M.A., Gómez, J.P., and Fierro, J.L.G., "New Catalytic Routes for Syngas and Hydrogen Production," Appl. Catal. A, Vol. 144, No. 1-2, 1996, pp. 7-57.

2. Dry, M.E., "Fischer-Tropsch Process: 1950-2000," Catal. Today, Vol. 71, No. 3-4, 2002, 227-241.

3. Schultz, H., "Short History and Present Trends of Fischer-Tropsch Synthesis," Appl. Catal. A, Vol. 186, No. 1-2, 1999, pp. 3-12.

4. Morales, F., Grandjean, D., Mens, A., de Groot, F.M.F., and Weckhuysen, B.M., "X-Ray Absorption of $\mathrm{Mn} / \mathrm{Co} / \mathrm{TiO}_{2}$ Fischer-Tropsch Catalysts: Relationships between Preparation Method, Molecular Structure, and Catalyst Performance," J. Phys. Chem. B, Vol. 110, No. 17, 2006, pp. 8626-8639.

5. Lira, E., López, C.M., Oropeza, F., Bartolini, M., Alvarez, J., Goldwasser, M., Linares, F.L., Lamonier, J.-F., and Zurita, M.J.P., "HMS Mesoporous Silica as Cobalt Support for the Fischer-Tropsch Synthesis: 
Pretreatment, Cobalt Loading and Particle Size Effects," J. Mol. Catal. A, Vol. 281, No. 1-2, 2008, pp. 146-153.

6. Li, J., Jacobs, G., Zhang, Y., Das, T., Davis, B.H., "Fischer-Tropsch Synthesis: Effect of Small Amounts of Boron, Ruthenium and Rhenium on $\mathrm{Co} / \mathrm{TiO}_{2}$ Catalysts," Appl. Catal. A, Vol. 223, No. 1-2, 2002, pp. 195-203.

7. Eri, S., Goodwin, J., Marcelin, G., and Riis, T., "Catalyst for Production of Hydrocarbons," U.S. Patent 4,801,573, January 31, 1989, pp. 11.

8. Martínez, A., Lopéz, C., Márquez, F., and Díaz, I., "Fischer-Tropsch Synthesis of Hydrocarbons Over Mesoporous Co/SBA-15 Catalysts: the Influence of Metal Loading, Cobalt Precursor, and Promoters," J. Catalysis, Vol. 220, 2003, pp. 486-499.

9. Rytter, E., Skagseth, T.H., Eri, S., and Sjåstad, A.O., "Cobalt Fischer-Tropsch Catalysts Using Nickel Promoter as a Rhenium Substitute to Suppress Deactivation,” Ind. Eng. Chem. Res., Vol. 49, 2010, pp. 4104-4118.

10. Espinoza, R.L., Visagie, J.L., Van Berge, J., and Bolder, F.H., "Catalysts,” U.S. Patent 5,733,839, March 31, 1998, pp. 14.

11. Gaussian03, Revision C.02, Frisch, M.J. et al., Gaussian, Inc., Wallingford, CT, 2004, URL: http://www.gaussian.com/.

12. Konstantin, M., Neyman, G.N. Vayssilov, N.R., "Transition Metal Clusters and Supported Species With Metal-Carbon Bonds From First-Principles Quantum Chemistry," J. Organomet. Chem., Vol. 689, No. 24, 2004, pp. 4384-4394.

13. Liddell, M.J., "Organometallic Clusters: What is an Appropriate DFT Treatment," J. Organomet. Chem., Vol. 565, No. 1-2, 1998, pp. 271-277.

14. Fournier, R.J., "Theoretical study of linear and bent CrCO, NiCO, and CuCO," J. Chem. Phys., Vol. 98, No. 10, 1993, pp. 8041-8050.

15. Gonzalez-Blanco, O., "Density functional study of the $\mathrm{Fe}-\mathrm{CO}$ bond dissociation energies of $\mathrm{Fe}(\mathrm{CO})_{5}$," J. Chem. Phys., Vol. 110, No. 2, 1999, pp. 778-783.

16. Sunderlin, L.S., Wang, D., and Squires, R.R., "Bond Strengths in First-Row-Metal Carbonyl Ions," J. Am. Chem. Soc., Vol. 115, No. 25, 1993, pp. 12060-12070.

17. Sunderlin, L.S., Wang, D., and Squires, R.R., "Metal (Iron and Nickel) Carbonyl Bond Strengths in $\mathrm{Fe}(\mathrm{CO})^{\mathrm{n}-}$ and $\mathrm{Ni}(\mathrm{CO})^{\mathrm{n}-»,} J$. Am. Chem. Soc., Vol. 114, No. 8, 1992, pp. 2788-2796.

18. Scovazzo, P., Poshusta, J., Dubois, D., Kaval, C., and Noble, R., "Electrochemical Separation and Concentration of $<1 \%$ Carbon Dioxide from Nitrogen," J. Electrochem. Soc., Vol. 150, 2003, No. 5, pp. D91-D98.

19. Jayne, K.D., Durando, M., Blakley, T., Formato, R., and Kimble, M.C., "Electrochemically Modulated Gas/Liquid Separation for In Situ Resource Utilization Process Streams," SBIR Phase I Final Report to NASA, Contract No. NNK06OM21C, July 2006.

20. Zhang, S., Zhang, Q. and Zhang, Z.C., Ind. Eng. Chem. Res., "Extractive Desulfurization and Denitrogenation of Fuels Using Ionic Liquids," Vol. 43, No. 2, 2004, pp. 614-622.

21. Esser, J., Wassercheid, P., and Jess, A., "Deep Desulfurization of Oil Refinery Streams by Extraction With Ionic Liquids," Green Chem., Vol. 6, 2004, pp. 316-322.

22. Zhang S. and Zhang, Z.C., "Novel Properties of Ionic Liquids in Selective Sulfur Removal From Fuels at Room Temperature," Green Chem., Vol. 4, 2002, pp. 376-379.

23. Bösmann, A., L., Datsevich, L., Jess, A., Lauter, A., Schmitz, C., and Wasserscheid, P., "Deep Desulfurization of Diesel Fuel by Extraction With Ionic Liquids," Chem. Commun., 2001, pp. 2494-2495.

24. Hepp, A.F., Linne, D.L., Landis, G.A., Wadel, M.F., and Colvin, J.E., "Production and Use of Metals and Oxygen for Lunar Propulsion,” J. Propul. Power, Vol. 10, No. 6, 1994, pp. 834-840.

25. Hepp, A.F., Landis, G.A., and Kubiak, C.P., "A Chemical Approach to Carbon Dioxide Utilization on Mars," in Resources of Near-Earth Space, edited by J. Lewis, M.S. Matthews, and M.L. Guerrieri, University of Arizona Press, Tuscon, AZ, 1993, pp. 799-818. 


\begin{tabular}{|c|c|c|}
\hline \multicolumn{2}{|c|}{ REPORT DOCUMENTATION PAGE } & $\begin{array}{l}\text { Form Approved } \\
\text { OMB No. 0704-0188 }\end{array}$ \\
\hline \multicolumn{3}{|c|}{ 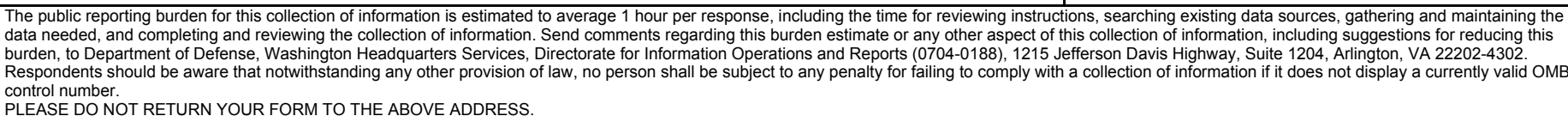 } \\
\hline $\begin{array}{l}\text { 1. REPORT DATE (DD-MM-YYYY) } \\
01-06-2011\end{array}$ & $\begin{array}{l}\text { 2. REPORT TYPE } \\
\text { Technical Memorandum }\end{array}$ & 3. DATES COVERED (From - To) \\
\hline \multirow{3}{*}{\multicolumn{2}{|c|}{$\begin{array}{l}\text { 4. TITLE AND SUBTITLE } \\
\text { Green Aerospace Fuels From Nonpetroleum Sources }\end{array}$}} & 5a. CONTRACT NUMBER \\
\hline & & 5b. GRANT NUMBER \\
\hline & & 5c. PROGRAM ELEMENT NUMBER \\
\hline \multirow{3}{*}{\multicolumn{2}{|c|}{$\begin{array}{l}\text { 6. AUTHOR(S) } \\
\text { Hepp, Aloysius, F.; Kulis, Michael, J.; De La Ree, Ana, B.; Zubrin, Robert; Berggren, Mark; } \\
\text { Hensel, Joseph, D.; Kimble, Michael, C. }\end{array}$}} & 5d. PROJECT NUMBER \\
\hline & & 5e. TASK NUMBER \\
\hline & & $\begin{array}{l}\text { 5f. WORK UNIT NUMBER } \\
\text { WBS } 387498.01 .04 .01 .07 .01 .03\end{array}$ \\
\hline \multicolumn{2}{|c|}{$\begin{array}{l}\text { 7. PERFORMING ORGANIZATION NAME(S) AND ADDRESS(ES) } \\
\text { National Aeronautics and Space Administration } \\
\text { John H. Glenn Research Center at Lewis Field } \\
\text { Cleveland, Ohio 44135-3191 }\end{array}$} & $\begin{array}{l}\text { 8. PERFORMING ORGANIZATION } \\
\text { REPORT NUMBER } \\
\text { E-17692 }\end{array}$ \\
\hline \multirow{2}{*}{\multicolumn{2}{|c|}{$\begin{array}{l}\text { 9. SPONSORING/MONITORING AGENCY NAME(S) AND ADDRESS(ES) } \\
\text { National Aeronautics and Space Administration } \\
\text { Washington, DC 20546-0001 }\end{array}$}} & $\begin{array}{l}\text { 10. SPONSORING/MONITOR'S } \\
\text { ACRONYM(S) } \\
\text { NASA }\end{array}$ \\
\hline & & $\begin{array}{l}\text { 11. SPONSORING/MONITORING } \\
\text { REPORT NUMBER } \\
\text { NASA/TM-2011-217027 }\end{array}$ \\
\hline \multicolumn{3}{|c|}{$\begin{array}{l}\text { 12. DISTRIBUTION/AVAILABILITY STATEMENT } \\
\text { Unclassified-Unlimited } \\
\text { Subject Categories: } 25 \text { and } 28 \\
\text { Available electronically at http://www.sti.nasa.gov } \\
\text { This publication is available from the NASA Center for AeroSpace Information, 443-757-5802 }\end{array}$} \\
\hline
\end{tabular}

\section{SUPPLEMENTARY NOTES}

\section{ABSTRACT}

Efforts to produce green aerospace propellants from non-petroleum sources are outlined. The paper begins with an overview of feedstock processing and relevant small

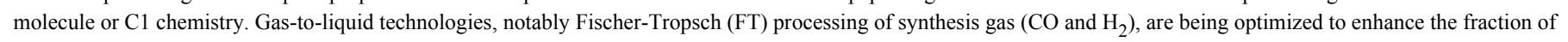

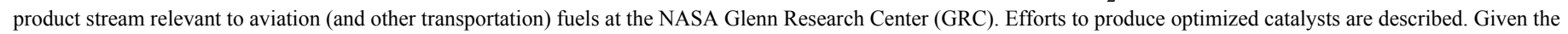
high cost of space launch, the recycling of human metabolic and plastic wastes to reduce the need to transport consumables to orbit to support the crew of a space station has

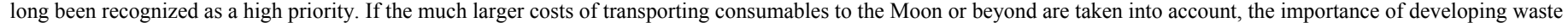

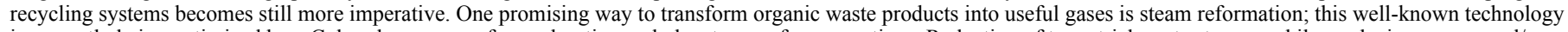
is currently being optimized by a Colorado company for exploration and planetary surface operations. Reduction of terrestrial waste streams while producing energy and/or valuable raw materials is an opportunity being realized by a new generation of visionary entrepreneurs. A technology that has successfully demonstrated production of fuels and related chemicals from waste plastics developed in Northeast Ohio is described. Technologies being developed by a Massachusetts company to remove sulfur impurities are highlighted. Common issues and concerns for non-petroleum fuel production are emphasized. Energy utilization is a concern for production of fuels whether a terrestrial operation or on the lunar (or Martian) surface; the term green relates to not only mitigating excess carbon release but also to the efficiency of grid-energy usage. For space

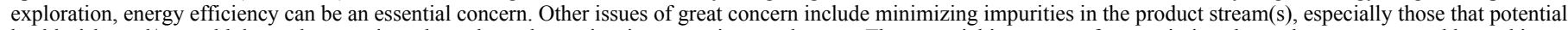
health risks and/or could de-grade operations through catalyst poisoning or equipment damage. The potential impacts on future missions by such concerns are addressed in closing.

\section{SUBJECT TERMS}

Catalysis; Fischer-Tropsch (FT) process; In situ resource utilization; Polymers; Waste utilization; Sulfur compounds; Electrochemistry

\begin{tabular}{|c|c|c|c|c|}
\hline \multicolumn{3}{|c|}{ 16. SECURITY CLASSIFICATION OF: } & \multirow{2}{*}{$\begin{array}{l}\text { 17. LIMITATION OF } \\
\text { ABSTRACT } \\
\text { UU }\end{array}$} & \multirow{2}{*}{$\begin{array}{l}\text { 18. NUMBER } \\
\text { OF } \\
\text { PAGES } \\
31\end{array}$} \\
\hline $\begin{array}{l}\text { a. REPORT } \\
U\end{array}$ & $\begin{array}{l}\text { b. ABSTRACT } \\
U\end{array}$ & $\begin{array}{l}\text { c. THIS } \\
\text { PAGE } \\
U\end{array}$ & & \\
\hline
\end{tabular}

\begin{tabular}{l} 
19a. NAME OF RESPONSIBLE PERSON \\
STI Help Desk (email:help@ sti.nasa.gov) \\
\hline 19b. TELEPHONE NUMBER (include area code) \\
443-757-5802
\end{tabular}



